\title{
History and development of methods in Recent benthic foraminiferal studies
}

\author{
JOACHIM SCHÖNFELD \\ Helmholtz-Centre for Ocean Research Kiel (GEOMAR), Wischhofstrasse 1-3, D-24148 Kiel, Germany \\ *Corresponding author (e-mail jschoenfeld@geomar.de)
}

\begin{abstract}
Benthic foraminifera have proven to be suitable for environmental monitoring because of their high levels of adaptation, small size and high abundance in Recent sediments and the fossil record. Foraminifera are scarcely used in monitoring studies because a standardization of methods has not been achieved to date. When particular methods were introduced and why they were applied is often hidden in the literature. This paper reviews the development of field and laboratory methods, their constraints and consequences for faunal and data analyses. Multiple and box corers and some grab samplers retrieve reliable surface sediment samples provided the bow wave is minimized as the sampler approaches the sea floor. Most disturbances are created during handling of the unit on deck and subsampling. Ethanol for preservation, rose Bengal as vital stain and a mesh size of $63 \mu \mathrm{m}$ to wash foraminiferal samples are used extensively. Faunal analyses of a larger size fraction are occasionally necessary. The fractions $>125 \mu \mathrm{m}$ and $>150 \mu \mathrm{m}$ are often preferentially chosen even though this may artificially reduce specimen numbers and faunal diversity. Generally, a much lower level of common practice prevails in sample preparation and faunal analyses than in sampling or laboratory procedures. Increasing preference has been given to quantitative methods and the acquisition of independently revisable census data during recent decades. J. Micropalaeontol. 31(1): 53-72, February 2012.
\end{abstract}

KEYWORDS: methods, benthic foraminifera, environmental indicators, sampling, laboratory procedures

\section{INTRODUCTION}

Marginal marine ecosystems today are seriously affected by global warming (e.g. Stachowicz et al., 2002; Smith, 2010), the first signs of ensuing ocean acidification (e.g. Cigliano et al., 2010; Thomsen et al., 2010; Haynert et al., 2011), the tremendous growth of mega-cities and the accompanying rise of industrial production in developing countries. The ongoing or foreseeable ecosystem deterioration requires effective governmental measures in order to achieve and maintain a healthy environmental status to facilitate a sustainable supply of fish, aqua-cultural and medical products for the local and regional population. Protective measures need a concomitant monitoring in order to assess the current status of marine environments. Monitoring programmes conventionally use the abundance and physical condition of certain organisms indicating pollution or human impact, or they use functional groups, diversity and other biotic indices (e.g. Borja \& Dauer, 2008; Josefson et al., 2009). Marine environmental monitoring has traditionally relied on macro-organisms. However, a growing number of studies have demonstrated that benthic foraminifera are also suitable for environmental monitoring because of their high degree of adaptation, species richness and population densities, which regularly exceed those of higher metazoans by orders of magnitude in near-coastal waters and beyond (Watkins, 1961; Schafer, 1973; Ellison et al., 1986; Sharifi et al., 1991; Alve, 1991; Alve \& Olsgardt, 1999; Yanko et al., 1998; Tomas et al., 2000; Debenay et al., 2001; Caruso et al., 2011). None the less, foraminifera are rarely used for monitoring purposes because there is no general agreement about which methods are to be applied.

Early studies of Recent foraminifera focused on species inventory and distribution. The majority of modern investigations are aimed at improving the understanding of benthic foraminiferal ecology in general or constraining the influence of specific environmental parameters. Under these objectives, it is necessary to assess the foraminiferal fauna living at the time of sampling, because the species composition is determined by biotic and abiotic factors that characterize their immediate environment (Murray, 2001; 2006). The dead assemblages may significantly differ from the living fauna in abundance and species composition due to different production rates of individual species, taphonomic loss of those tests, which are more susceptible to degradation and dissolution, and due to re-deposition (e.g. Murray, 1982). Dead assemblages were built up over many generations and closely resemble fossil assemblages from the sedimentary record. As such, dead assemblages or assemblages reduced by non-fossilized species have often been considered as calibration data for palaeoreconstructions (e.g. Lutze et al., 1986; Schönfeld, 2002a; Hayward et al., 2011).

Studies of Recent benthic foraminifera provide us with a valuable and permanently growing background dataset on the ecology and distribution of living species (Murray, 2006, and supplementary online material), which can be used both as a regional reference for environmental monitoring and the calibration of foraminiferal proxies in palaeoceanography and palaeobathymetry. A few regional compilations have been attempted in order to compile the faunal inventory for certain areas (Atlantic N. America Culver \& Buzas, 1980; New Zealand - Hayward et al., 1999; Gulf of Mexico - Sen Gupta \& Smith, 2010). Apart from taxonomic inconsistencies, these and other approaches are largely hampered by the fact that most of the data from the considered studies were created by using different field and laboratory methods (e.g. Schönfeld, 2006, p. 357). The methods were often not clearly reported so that adaptive algorithms could not be developed to integrate the faunal information from different sources. Furthermore, it is not clear, to date, how the choice of methods for a benthic foraminiferal study would affect the accuracy of the results.

There are only a few studies where two or more different methodologies were compared directly. One aspect of these comparisons is the effect of different sieve mesh sizes on the faunal composition and structure (Schröder et al., 1987; Van Marle, 1988; Timm, 1992). Another subject is staining techniques facilitating the recognition of foraminiferal specimens that were living 
at the time of sampling (Walker et al., 1974; Bernhard, 1988; 2000; de Nooijer, 2007). These studies highlighted the differences between the methods rather than making persuasive recommendations that were generally followed in most subsequent investigations. Instead, there are scattered notes in many papers that similar comparisons were made, and that the methods for the particular study were chosen or adapted accordingly, but these tests were not sufficiently documented. Whether the experiences were communicated among different groups or whether the tests were repeated independently is not clear. The acceptance, utility and development of the methods can be revealed only if they are tracked through the literature.

The influence of sampling techniques and sea-going devices is scarcely ever noted (e.g. Smith \& Howard, 1972). However, there are techniques and protocols readily available which have evolved from long-standing experience. According to personal experience, they were not communicated, not even within a working group. Instead, they were kept as strategic knowledge, probably because of the consequences for the success of research cruises. The tradition of this knowledge was, therefore, confined to a very few cruise participants. The advantages and limitations of sampling methods can be constrained only if scattered information from cruise reports is combined with a functionality description of the devices. Then, the reasons for many effects may emerge.

The aim of the present paper is to review in a historical perspective both field and laboratory methods that have been used in Recent benthic foraminiferal studies. Emphasis is given on when and how they have been introduced and why they were applied. Consequences for subsequent faunal and data analyses are highlighted. Recommendations are not intended here although they are self-explanatory in places.

\section{INFORMATION SOURCES}

The present study relies on a considerable collection of offprints and authorized copies of papers on Recent benthic foraminiferal studies, as well as on $\mathrm{PhD}$ and unpublished Diploma and Master theses. The papers are supplemented by hundreds of digital PDF documents of recent papers from online resources.

In order to create robust figures on the use of particular methods, a compilation has been made from all papers on Recent benthic foraminifera published from 2008 to 2010 in the Journal of Foraminiferal Research, Journal of Micropalaeontology and Marine Micropaleontology. A similar compilation has been made for the publication years 1978 to 1980 in the Journal of Foraminiferal Research and Marine Micropaleontology to describe the use and documentation of methods 30 years ago. The Journal of Micropalaeontology was not yet established at that time.

The information on sampling methods and sea-going devices is based on personal experience that has been gained on twelve research cruises since 1991 and many excursions to salt marshes and tidal flats in western Europe. Primarily, technical knowledge has been collected during more than 25 years of affiliation with institutes pursuing Marine Science at Kiel, Hannover and Bremen, Germany.

\section{SURVEY CONCEPTS AND SAMPLING SCHEMES}

Early micropalaeontologists working on the fossil record collected their samples on individual journeys to certain locations (e.g. d'Orbigny, 1839). Other microfossil workers relied on samples that were sent from colleagues participating on various expeditions (e.g. Goës, 1894). Systematic studies on distributions of Recent foraminifera were mostly conducted as an add-on to biological or geological investigations during sea-going expeditions. Early examples are Egger (1893), Heron-Allen \& Earland (1913) and H. B. Brady (1884). The tradition continued through Parker (1958) describing benthic foraminifera from samples collected during the Swedish Deep Sea Expedition, samples from the Netherlands' Orinoco Shelf Expedition (Drooger \& Kaasschieter, 1958), the annual R/V Polarstern route from Cape Town to the Georg-von-Neumeier Antarctic Station (Mackensen et al., 1993) and personal investigations off southern Portugal (Schönfeld, 1997). The common conditions of such add-on studies are that the participating micropalaeontologists or persons in charge had only limited planning influence on the location of samples, their total number and, in particular during deep-sea expeditions, the choice of sampling device. Sample sharing was and still is usual, it is deemed to be appropriate and cost effective and this procedure has often conferred other limitations concerning sample size, sieve size or method of preservation.

In the early days, sampling was not done in such a systematic way with extensive areal coverage that would be appropriate for a modern environmental survey. There are established concepts from vegetation surveys or near-shore biological investigations (Braun-Blanquet, 1964; Davies et al., 2001; Rachowicz et al., 2006). These schemes have been thoroughly tested (e.g. Thompson \& Seber, 1996) and widely applied, but they were mostly not followed with respect to foraminiferal studies. Once fieldwork or part of a cruise was dedicated to a Recent foraminiferal survey, sampling was performed mostly along transects that were placed perpendicular to the governing or supposed environmental gradients. They were mostly transects versus depth crossing the shelf and continental margin (e.g. Lutze, 1980; Van Marle, 1988), along an estuary (e.g. Phleger \& Lankford, 1978; Wang, 1983; Diz \& Francés, 2008) or from the high salt marsh to a tidal channel (Scott \& Medioli, 1980; Horton, 1999; Gehrels \& Newman, 2004; Berkeley et al., 2009). This strategy was deemed a compromise to capture a maximum of environmental variability with only those samples that were essential to depict the assemblage structures. Transects were combined and gaps were filled on subsequent cruises, as defined by the data structures from previous surveys. This evolving information density created a rather irregular pattern and the reasoning was not always obvious from the final sample distribution (e.g. Jorissen, 1988; Nikulina et al., 2008). Another strategy was to work up a regular sample grid that was defined in advance of the survey. This strategy was applied mostly in lagoons or embayments (e.g. Lynts, 1962; Lutze, 1968; Otvos, 1978). A third concept, the 'Hausgarten', is characterized by fixed stations in a well-defined area, for instance Bokniseck in the Baltic Sea (Lutze, 1965; 1974; Schönfeld \& Numberger, 2007), Plateau des Landes in the Bay of Biscay (Fontanier et al., 2002; 2003; Langezaal et al., 2006; Barras et al., 2010) or Sagami Bay, Japan (Kitazato et al., 2009 and references therein). These locations were revisited from time to time. Adjoining investigations of the hydrography, plankton or benthos biology provided a comprehensive background dataset for ecological interpretations. However, an appropriate sampling scheme has to be established for repetitive sampling in a small area as each sampling event will disturb 
the environment. Full recovery of the fauna may take months and this might affect the number of living individuals in the sample from the following event.

\section{HANDHELD SAMPLING Sediment surfaces}

Different strategies were applied for sampling in salt marshes, tidal ponds and lagoons or at the beach. They were poorly documented in literature (except, for example, Boltovskoy \& Wright, 1976; Murray \& Alve, 2000) and it is not clear how they have been developed. Spatulas, shuffles, spoons and small dredges have been used, and the samples placed in simple bags, all kinds of plastic vials or even recycled glassware. These were bulk samples and did not consider any depth distribution of foraminifera in the sediment or the intention to approach a certain sample volume. They also included the possibility that part of the material was lost. Other sampling techniques involve cut-off syringes, tubes or stainless steel cylinders (e.g. Scott \& Medioli, 1980). The tubes may capture supernatant water, and they provide a certain standardization, either in volume of the entire sample with depth, or with reference to the surface area. The third concept was to apply rings or frames with a given surface area and sample thickness that was already defined with deployment. These frames required an active decision after a visual impression of where the sample was to be taken in relation to micro-topography, structures or supposed surface preservation. The content of the frame was spooned out or the sampler and sample were lifted out after being detached by pushing a blade or Japanese spatula beneath. A fourth and rarely used method was contact coring (Honeywill et al., 2002). The unstable viscous surface layer is frozen with a pan and liquid nitrogen. The sample is then scraped off the bottom of the pan and collected in a plastic vial. The surface area is quite well defined, but the sampling depth depends on the freezing duration.

\section{Elevated substrates}

Different sampling procedures and data acquisition schemes were applied for studies of phytal foraminifera or species recruiting other elevated substrates. Seagrass leaves, stems or clumps of macroalgae were extracted by hand or cut off with a knife or scissors when diving or wading in shallow waters (e.g. Langer, 1993; Wilson, 1998; Debenay \& Payri, 2010). Distance to the shore, water depth and plant communities were noted (e.g. Wilson, 2008). Some studies considered all plants growing on an area of $25 \mathrm{~cm}^{2}, 64 \mathrm{~cm}^{2}$ or $100 \mathrm{~cm}^{2}$ (Fujita \& Hallock, 1999; Semeniuk, 2000), others took their samples randomly. The lengths, widths or diameter of branches or stems were noted. This allowed calculation of population densities of attached foraminifera in relation to the immediate surface area of their substrate. The seaweeds or algae were kept in plastic bags with ambient seawater or they were immediately frozen or dried for long-term preservation. Elevated substrates, such as pebbles, coral fragments, shell debris, sponges and hydrozoans, were either collected by scuba divers or they were retrieved by grabs or box cores, as described below (Oschmann, 1990; Hohenegger et al., 1999; Schönfeld et al., 2011). The substrates were carefully removed from the surface sediment with a pair of tweezers or a knife and placed into plastic vials for preservation with methanol or ethanol, or they were put in plastic bags and boxes with ambient seawater for immediate processing. The height of attached foraminifera above the sea floor was inferred at a level below where traces of sediment were still sticking to the object. The horizontal dimensions of the elevated objects were also recorded (Baker et al., 2009). This allowed a calculation of population densities as referred to the area where the substrate covered the sea floor (Schönfeld, 2002b). One of the major problems with sampling phytal or epibenthic foraminifera is that they tend to drop off their substrate during transport and handling. According to personal experience, this may affect up to a fourth of all attached specimens from a particular object and certain species are more susceptible to detachment than others. As such, sample vials or bags have to be screened thoroughly for lost specimens after sample processing.

\section{REMOTELY OPERATED DEVICES}

Remotely operated sampling devices are dredges, corers or grab samplers that are deployed from small and large vessels, platforms, bridges or piers. Up to a weight of $20-30 \mathrm{~kg}$ and to a water depth of approximately $40-50 \mathrm{~m}$ they can be operated by hand, according to my experience. At greater depths, one cannot feel with certainty when the device touches the sea floor. A winch with rope tension indicator is then required.

\section{Sediment corers}

Corers are the most commonly used devices. They were initially developed from the lead weights used for soundings that were invented by Greek seafarers in the sixth century BC (Oleson, 2000). The weights have a little hole at the bottom, the tallow cup, filled with grease revealing the composition and stability of some recovered sediment sticking to it. This information was needed primarily to determine a sea floor suitable for anchorage. The sediment texture and composition was noted in the logs and is often documented in nautical charts. Even some recent electronic charts still contain this information. Since the middle of the nineteenth century, a small tube has been attached to the weight to obtain more material, for instance Brooke's 1853 sounding apparatus. The concept has prevailed until today in the Vax corer that is mainly used by volcanologists. Bottom samples from the HMS Challenger expedition were taken with an, at that time advanced, Baillie Sounder, which was the first genuine gravity corer (Tanner, 1897). As the coring tubes became longer and the weights became heavier, core catchers were invented to prevent the core slipping out. Triggering devices and valves steering the water flow through while penetrating the sediment and hold-on recovery were also developed. The basic principles were established in the 1950s to 1970 s. For a detailed description of various sediment coring devices, their technologies and constraints, see Mudroch \& MacKnight (1994) and Scott et al. (2004).

There are two aspects of major importance: (1) the preservation of the near-surface sediment and ways to improve this; and (2) the term 'core-top sample'. It is a given fact that the coring process of conventional gravity or piston corers includes rough handling and fast penetration (usually more than $50 \mathrm{~cm}$ per second). A small bow wave of water stirs up and flushes away the delicate fluffy surface layer of fine-grained sediment immediately before the nose cone of the corer touches the sea floor (McIntyre, 1971). Furthermore, the core catcher is an obstruction for semi-liquid nearsurface sediments and its resistance diminishes with penetration depth. This is not a major problem when the near-surface sediment is stabilized by sand-rich layers or biodetritus. In soft sediments, 


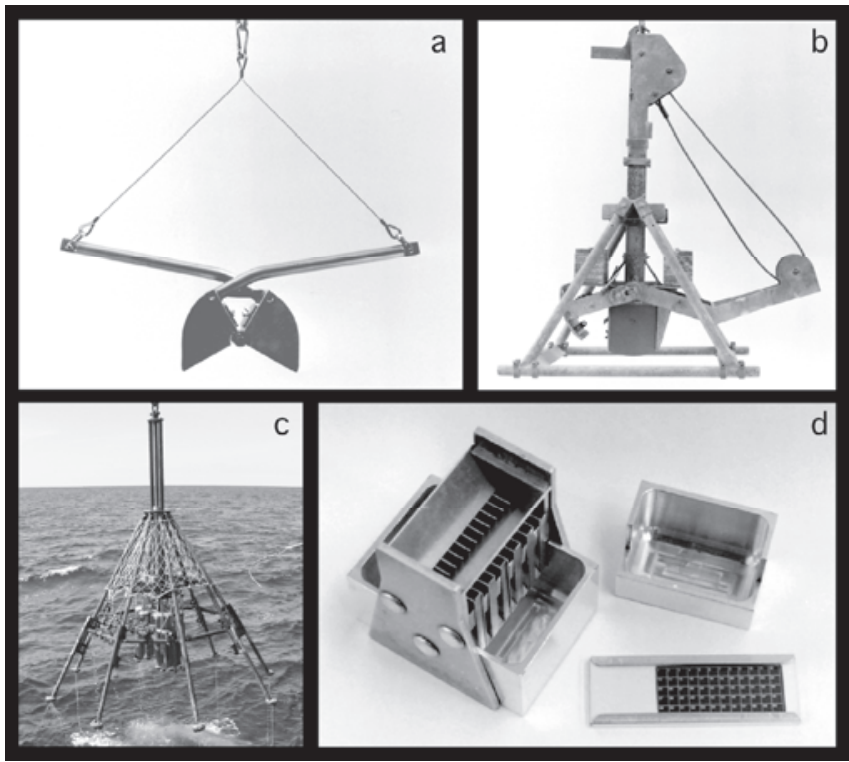

Fig. 1. Sampling devices and preparation utensils used in Recent benthic foraminiferals studies: (a) Van Veen grab (width of jaws in open position is $17 \mathrm{~cm}$ ); (b) Reineck box corer (width of frame is $100 \mathrm{~cm}$ ); (c) multicorer at sea on sample recovery (photo: Thorsten Garlichs, Kiel; height of device is $415 \mathrm{~cm}$ ); (d) microsplitter and Plummer cell slide (length of slide is $7.5 \mathrm{~cm}$ ).

however, the uppermost part of a sediment core may have the shape of an elongated sugar cone lying loosely on one side of the liner. Suspension or crumbs of near-surface sediment may fall in the remaining void during core recovery. One may recognize this as yellowish veneer on the inside of the liner after the core has been opened. Stabilization of the loose top with a plug of rubber, cork or elastic foam has often been undertaken, though it may induce a slight compression of the uppermost strata and this significantly reduces the calculated late Holocene sedimentation rates.

When the liner with the sediment core is cut into $1 \mathrm{~m}$ or $1.5 \mathrm{~m}$ long segments, the core in the uppermost segment is pushed a little bit up and a 'core-top sample' of a few millimetres up to $1 \mathrm{~cm}$ thickness is regularly scraped off and kept in a separate vial or plastic bag. Overlying water with its suspended material from the uppermost part is also commonly added to the core-top sample. This blend is at the disposal of all cruise participants and it is immediately subdivided among them to be used as a surface sediment reference for the respective coring station. Extensive surface distribution maps were created from these core-top samples (Lohmann, 1978; Bremer \& Lohmann, 1982). In particular in the Southern Ocean or central Pacific, core-top samples were the only possibility of obtaining any kind of near-surface sediment. However, radiocarbon dating indicates that core-top samples may include microfossils with an average age of several thousand years (e.g. Dowsett et al., 2003; Regenberg et al., 2009). Off southern Portugal, the living benthic foraminiferal assemblage from a core-top sample retrieved with a small gravity corer and plastic core catcher corresponded to a level of 1-3 cm below sediment surface (Schönfeld, 1997; 2001).

The Phleger corer, Rumohr corer, minicorer or multicorer were especially designed to take surface samples without the distortion by a core catcher (Phleger, 1951; Meischner \& Rumohr, 1974; Barnett et al., 1984; Kuhn \& Dunker, 1994). A single tube or an array of 4-12 plastic tubes (multicorer) is gently pushed into the surface sediment and short cores with supernatant water are recovered (Fig. 1). Once the corer is back on deck and the tube with the core is dismounted from the array, the base is secured with a plug. The core is temporarily stored in a rack or simply lashed to a post or laboratory furniture. Multicorer tubes have to be handled with extreme care, but one often sees that the tubes are not kept sufficiently stable by nervous or excited staff. Water movements stir up surface sediment, the core may get loose and little crumbs of surface sediment fall into the opening void between the sediment core and the plastic tube. For sampling, the multicorer tube is lifted on a post with a piston fitting to the inner diameter of the multicorer tube (Murray, 2006, p. 10). The supernatant water is drained off through a hose, and the core is pushed up through the tube until the surface appears at the upper end. It is pushed further upward in increments of 3-20 mm, the respective slices are held with a shorter tube segment, cut off with a spatula and are usually stored in vials, petri dishes or plastic bags. This procedure of 'multicorer slicing' commonly follows a fixed scheme, which may be individual among different institutions. The scheme is defined at home or agreed upon in advance. The slice thicknesses are thus only seldom adapted according to different findings.

A difficulty which is rarely tackled is how to precisely define the zero level of the sediment surface. The surface is often rough, crumbly and tilted in most cases. Some workers assign zero to the upper end, others to the middle and some to the lower end of the slope. A surface sediment sample of such a tube may comprise strata of up to more than double the thickness that was initially intended. The subsequent slicing transposes this uncertainty further downwards. Pushing the core upwards through the tube may also displace some material to lower depths. Depth distributions of living foraminifera in the sediment may then become disturbed and include unexpected depth ranges of shallow-living taxa (C. Fontanier, Angers, pers. comm. 2008). It is often assumed that all cores from the array represent the same succession. However, from the lack of continuity it cannot be verified that surface and subsurface strata are continuous between the cores as they are studied in a horizontal sense and not vertically as other cores or outcrop sections. Differences in microfossil contents of surface samples from different tubes of one deployment were often attributed to patchiness (Barras et al., 2010), although this has been proven by independent evidence or corroborated by seabed images in only a very few cases to date (Heinz et al., 2005; Erbacher \& Nelskamp, 2006). Video images from telemetry cameras indicate that multicorer penetration is very slow and usually not continuous. Sudden bumps stir up huge clouds of suspension material which may invade the tubes that are still open at the top. It is conceivable that this may blur lateral patchiness. None the less, the multicorer, Rumohr corer, minicorer or similar devices are widely accepted as being the most reliable method to take foraminiferal samples (Blomqvist, 1991; Bett et al., 1994).

\section{Grab samplers}

Grabs were invented by coastal engineers and sedimentologists. There are various types of two-jaw samplers, such as Petersen, Ponar, Murray or Van Veen grabs (Petersen, 1911; Van Veen, 
1936; Murray \& Murray, 1987). Their basic design resembles a cable dredge from the early days used in earthworks. They descend to the sea floor open in a locked position, the jaws are released on bottom contact and closed when the device is hoisted again. The most commonly used Van Veen grab was designed to take bulk samples of technical quality and volume (Fig. 1). It was not intended to accurately maintain the integrity of the near-surface sediments. Video images taken by divers showed that, indeed, some near-surface sediment might fall out between the jaws when the grab closes. Once a pebble or shell obstructs closure, a part of the sample is washed out. This may be seen as a faint trace of sand on deck when the grab is moved from the winch to the workplace. However, whether some material has been washed away is not always recognizable from the visual inspection of the sample surface. Small Van Veen grabs are simply emptied in a bucket so that any sedimentary structures are distorted. Such samples are certainly inappropriate for surveys on Recent foraminiferal assemblages. Other grabs have lids on top of the jaws that can be opened to facilitate both description and sampling of the sediment surface. The Van Veen grab has often been criticized for only scraping the surface and collecting an undefined portion of the underlying strata. However, an appropriate design and precise manufacturing can improve the sample authenticity significantly (Riddle, 1989).

The main advantage of grabs is, however, that it is at least possible to get samples from sands, pebbles or veneers of lag sediments where a multicorer fails. In high-energy environments, foraminifera often prefer to live attached to stable objects, or they are very rare because of the frequent sediment re-deposition (Schönfeld, 2002a, b). These patterns may be revealed by grab sampling only. It has to be noted, however, that approximately every other deployment fails and the grab returns empty in such environments. This may also be a problem of navigation, of keeping the vessel stable when currents are strong or high waves prevail.

The Shipek Grab involves a different technology (Shipek, 1965). This grab has a top half-cylinder barrel with a second halfcylindrical shovel that is activated by a spring mechanism. When the grab touches the seabed, the second cylinder rotates by $180^{\circ}$ through the sediment, cuts off the sample and closes with the upper half-cylinder barrel. The sample is accessible for description and subsampling when the second cylinder is dismounted from the upper assembly. The high-torque spring mechanism may cut through pebbly and shell sands. Objects of $3 \mathrm{~cm}$ in size are pushed away and do not obstruct the closure. Epizoans in life position on larger objects prove that the texture and orientation of the surface sediment is mostly intact on retrieval (Janßen, 2011). Shipek grabs are not easy to arm and the self-release mechanism with high torque forces makes it dangerous to the operator in rough seas.

\section{Box corers}

Box coring devices include the Reineck, Soutar and USNEL giant box corer, as well as the Birge-Ekman and Smith-McIntyre grab sampler (Smith \& McIntyre, 1954; Reineck, 1958; Bouma \& Marshall, 1964; Soutar et al., 1981). They provide a bridging technology between genuine grab samplers and coring devices. Box corers were designed to retrieve both a well-preserved sediment surface and a short core from coarse- or fine-grained near-surface sediments. The core is rectangular and allows the three-dimensional description of biogenic and sedimentary textures. The surface allows the recognition of traces or sedimentary structures that can be compared with the corresponding subsurface features. The examination of box cores is, therefore, a valuable approach in facies analysis. However, the dimensions of the core limit the scope of the recognized features. For instance, the Reineck box corer usually has a size of $20 \times 25 \mathrm{~cm}$, the Soutar box corer $30 \times$ $30 \mathrm{~cm}$, a Birge-Ekman grab $13 \times 13 \mathrm{~cm}$ and the USNEL giant box corer has a surface area of $50 \times 50 \mathrm{~cm}$. The penetration is usually not deeper than the maximum width of the box. Any larger sedimentary structures are not captured.

The box corer consists of a frame, which stands on the seabed, a coring unit that is centred in the frame and two spring-loaded jaws or a spade that is pushed under the core immediately before the corer is drawn back to the surface again (Fig. 1). The spade or jaws hold the core during recovery. Flaps on top of the corer are open during descent to let the water flow freely through the box during penetration. The flaps are closed on recovery. The coring process itself and subsequent recovery involve some complications, which may affect the quality of the sample (Wigley, 1967). The first is the moment when the device touches the seabed. The frame touches the sediment first and may stir up a cloud of sediment, in particular when the ship's movements are felt at depth. A box corer dredging or jumping on the seabed has less penetration, retrieves inclined sediment surfaces, and often the spade does not hold the core accurately so that some sediment is washed out. The spade may also be obstructed by a pebble or shell, which induces the same effects as with grab samplers. The other delicate moment is when the box corer is hoisted through the sea surface and is placed on deck. Once the box is raised above water level, a large quantity of supernatant water on top of the sample puts it under pressure and may flush it out through the slit between the box and spade. Mostly, the spade has a rubber seal keeping the box tight under rope tension. Once the tension is released when the box corer is set on deck, the near-surface sediment may be washed out within seconds. It is a necessary - though difficult - task to draw off most of the supernatant water with a hose while the sampler is hanging on the line and before it is set on deck. The ship's movements during these minutes may induce a wave in the box, which may wash the sediment surface, stir up and displace some surface sediment. This affects little puddles in depressions, in particular. It is an urgent and delicate matter to remove all water from the sediment surface to keep it stable and to quickly drain the puddles with syringes. These operations have often been criticized, as it is not clear whether and how much material in suspension is lost during draining the box corer. Effluent material may be captured if the water from the hose is rinsed through a sieve. Such samples collected from supernatant water usually contain some planktonic foraminifera or pteropod shells, but seldom benthic foraminifers that were living at the time of sampling. The sediment surface recovered by box cores is seemingly well preserved. Parallel sampling with box corer and multicorer has revealed a consistent pattern of generally higher meiofaunal densities in surface samples from multicorer deployments as compared to those from box cores (Bett et al., 1994). Surprisingly, the population densities of benthic foraminifera were higher in samples from box core surfaces than in multicorer samples with the same thickness (Shirayama \& Fukushima, 1995; Schönfeld, 2001). The number of observations is too low, however, for a robust statistical treatment 
corroborating the significance and possibly elucidating the background reasons for these observations.

Subsampling of box core surfaces for foraminiferal studies is performed in similar ways as hand held sampling on tidal flats. Small push cores are used for subsequent slicing to sample deeper levels for foraminiferal microhabitat studies. Rings or frames with a defined area and height are used to collect a standardized surface area and volume. In any case, an active decision has to be made where the sample is to be taken from the box core surface. There are two different strategies. In the first, a representative coverage of different micro-topographies or surface sediment textures is attempted. This can be done by taking separate samples from each unit and analysing them separately. This strategy is based on the assumption that the different micro-topographic units house a different microfauna. However, such samples are considered pseudoreplicates as they do not increase the degrees of freedom available for statistical testing (Hurlbert, 1984). The other strategy is to place the frame into a transition zone representing the different supposed microenvironments with the same proportions as on the whole box-core surface, or to pool samples of respective volumes taken from different places on the surface. This strategy increases the sample size in general and gives the opportunity of recording a higher diversity through the higher probability of capturing rare taxa (Dennison \& Hay, 1967; Douglas et al., 1978). It also bears the underlying assumption that the box corer is an accidental subsample of the sea floor, which therefore is considered as being representative of a wider area in the scale of hundreds of metres. Any significant replicate should then be an external replicate as an individual sample from another deployment. A test where an entire box core surface was subdivided into different subsamples, which were analysed separately, revealed no convincing results on which of the above-mentioned strategies should be preferred on a routine basis (Kuhnt et al., 2005).

\section{SAMPLE PRESERVATION AND FIXATION}

When a foraminiferal sample has been taken it cannot usually be examined immediately and thus needs to be stored for a certain time. During storage the original structure and composition of the foraminiferal assemblages should be preserved. The simplest way is the aquatic approach, which has been followed since the earliest days of foraminiferal studies. The sample is submerged under a few centimetres of seawater and kept under the ambient temperature in a refrigerator or thermobox. The sample vial is not sealed tightly in order to allow access for oxygen. This leads to evaporation and, therefore, the salinity has to be controlled regularly and kept in the range of natural variability at the sampling site (Fontanier et al., 2008). A foraminiferal sample can be kept that way for months. However, it has to be noted that the natural setting of abiotic and biotic environmental factors cannot be maintained completely under laboratory conditions. In particular, the ambient pressure for assemblages from the deep sea and the natural food supply can hardly be simulated. This induces unexpected behaviour in certain species (Anderson et al., 1991) or even longterm shifts in assemblage composition (Alve, 2010).

A very simple way of preservation is to freeze a sample immediately on collection and to store it in a freezer. It is also possible to wash a sample right away with seawater through a sieve, to desalt the residue under tap water and to dry it. The residue can be kept for later analysis. Deep-sea samples were commonly preserved that way in the early days since the time of Egger (1893). However, this procedure does not enable specimens that were living at the time of sampling to be distinguished from empty tests. Only in very rare cases (for instance, foraminifera from the Dutch Wadden Sea; Hofker, 1977) was such recognition of living and dead specimens possible, based on dried samples.

The most common way of preservation is to add a chemical to the sample which terminates the metabolic and enzymatic activity of all organisms but does not damage or dissolve the foraminiferal tests. Since the nineteenth century, alcohol has been used to preserve foraminiferal samples. Ethanol of technical or analytical quality is generally used. Such alcohol of high concentration is now banned in several countries or charged with high taxes. Therefore, it is recommended that methanol or isopropanol are used instead of ethanol. It should be noted, however, that methanol is toxic and the less toxic isopropanol is reported to dissolve foraminiferal protoplasm (Walker et al., 1974, p. 208).

For optimal sample preservation, an alcohol concentration of $70 \%$ is recommended (Murray, 2006), but it is also widely used at high concentrations of more than $90 \%$ (e.g. Fontanier et al., 2008; Mojtahid et al., 2009; Schönfeld et al., 2011). Some micropalaeontologists first wash the sample on a mesh and then preserve the residue with alcohol. Others pour the alcohol directly onto the sediment sample and use it also as diluter or carrier for vital stains. It has to be noted, however, that the alcohol concentration should not be too high. Spirits of technical quality with $98 \%$ or even absolute alcohol induces osmotic pressure during mixing and leads to the collapse of organic cells, for instance from algae or bacteria. Soft-walled foraminifera and gromiids may also become damaged. This can be seen by eye when the sample becomes whitish for a while due to coagulating cell proteins and the sample vial gets warm. It is also conceivable that the collapse of food or water vacuoles in foraminiferal protoplasm and the fast dehydration leads to a shrinking of the protoplasm and may cause an irregular staining pattern. In general, an addition of 1.5 times volume of alcohol with reference to the sample volume is recommended (Lutze \& Altenbach, 1991). The alcohol concentration in the blend is then $60 \%$ at maximum depending on the amount of pore water from the sediment. After preservation, the sample is to be shaken for at least one minute to ensure complete mixing (Lutze, 1964; Murray, 2006).

The security measures implemented after the attack on the World Trade Center, USA, in September 2001 and new transport safety rules drew the attention of Security and Customs to foraminiferal samples preserved with alcohol. According to the regulations, the samples are inflammable substances classified as dangerous goods if the flashpoint is above a temperature of $61^{\circ} \mathrm{C}$. Dangerous goods have to be transported appropriately labelled, with declarations, and under specific conditions, which is costly and time consuming. They are generally excluded from commercial airfreight and banned from the luggage of aircraft passengers. This can be circumvented if the flashpoint is kept under $61{ }^{\circ} \mathrm{C}$ by using an alcohol concentration of less than $30.5 \%$ for transport, which can be achieved by dilution of three parts alcohol with seven parts water. Under such a concentration of $30 \%$, the preserved foraminiferal samples can be dispatched without declaration as dangerous goods. However, the concentration should not be lower than $20 \%$ and the samples should be kept below $10^{\circ} \mathrm{C}$ to avoid infection with acetobacteria. After transport, the alcohol 
concentrations should be raised to at least 50\% if longer storage of the samples is intended (A. Altenbach, Munich, pers. comm. 2011).

When the protoplasm, cell organellae, or generally foraminifera living at the time of sampling are the focus of interest, a fixative is needed that preserves the protoplasm between the time of sample collection and subsequent analyses. Fixatives are added to washed sample residues or plankton samples and not to bulk surface sediments, which still contain the fine fraction. The most common fixative is formaldehyde, which was introduced by marine biologists working with meiofauna and macro-organisms in the early twentieth century. The application of formaldehyde concentrations ranging from $2-20 \%$ in seawater are reported but commonly a concentration of $4 \%$ is used. The volume of the formaldehyde solution added should be higher than ten times the sample volume. Minimum fixation times are 6-24 hours, depending on the size of the organisms. Pure formaldehyde solutions tend to become acidic with time through dissociation to formic acid. Therefore, the $\mathrm{pH}$ has to be kept in the basic range to avoid dissolution of calcareous tests. The formaldehyde-seawater solution is, therefore, buffered with hexamethylentetramine and adjusted to a $\mathrm{pH}$ of 8.0 to 8.5. After some weeks in formalin, the protoplasm becomes firm, which might impede a later impregnation with non-vital stains. It has to be noted that formalin is highly toxic, that gloves have to be worn during fixation and that the treatment has to be done in a well-ventilated place. Such safety requirements might be the reason why only 2 of 45 studies (4\%) published from 2008 to 2010 used formaldehyde solution for fixation (Table 1). Thirty years ago about half of the studies (5 of 11, 45\%) published from 1978 to 1980 used formaldehyde for preservation and fixation (Table 2). Another fixative is glutaraldehyde. It was introduced in the 1960s and is especially suitable for preserving cellular ultrastructures. Glutaraldehyde is applied to specimens that are prepared for Transmission Electron Microscopy or genetic analyses. Glutaraldehyde is applied in a concentration of $2.5 \%$ in seawater; it is moderately toxic and may cause eye and skin sensitization. Gloves and safety goggles have to be worn during fixation

\section{STAINING}

There is hardly any other methodological aspect of foraminiferal studies which has been under such long and controversial debate as staining and the secure recognition of specimens living at the time of collection. The pioneering studies on population structures, growth and reproduction, taphonomy and sedimentation of Elphidium species from Plymouth Sound, England by Myers (1942a, b) first addressed the need to identify specimens that were living at the time of sampling in their natural environment. The identification was first made through the natural colour of the protoplasm. Later, the tests of formaldehyde-fixed specimens were dissolved and biological stains were applied to the protoplasmic casts. The sensitivity of living foraminifera to biological stains has been known since Rhumbler (1935), who reported specimens in life positions that were stained with Eosin and Methylene Green. However, these methods were not widely used before the 1960s (e.g. Phleger, 1952), because field studies on the biology, ecology and distribution of Recent foraminifers were rare or had a taxonomic focus.

With the increase in surveys to create reference datasets for environmental, palaeoecological or evolutionary investigations, Walton (1952) provided a staining method to differentiate between living and non-living foraminifera. Living specimens were pre-fixed in a buffered solution of formaldehyde and then submerged in a solution of 1 gram rose Bengal per litre seawater for 10 minutes. Others reported staining times of 20 minutes up to 48 hours (Boltovskoy \& Wright, 1976; Bernhard et al., 2006). Afterwards, the specimens were washed again on a sieve to remove the excess dye. Rose Bengal has a strong affinity to proteins, thus, after the treatment, the protoplasm is pink-coloured like a ripe raspberry. However, the pre-fixed protoplasm was too stiff and the internal foramens of the tests were often too narrow or plugged and thus did not facilitate a complete impregnation of the test infill with rose Bengal during the short staining period. This resulted in the frequently observed feature that the final one or two chambers are well stained and the protoplasm in the earlier part of the test is still its natural colour (yellowish-brown or green). Bandy introduced to his research group and Lutze (1964) described a modification of the rose Bengal staining procedure. They suggested dissolving rose Bengal in the preserving agent at a concentration of 1 or 2 grams per litre alcohol, and directly applying it to the surface sediment sample. An optimal impregnation of the tests was accomplished after storage of 3 or 4 weeks. According to my experience with samples from tidal flats of the German Wadden Sea, one may still find specimens in the samples where the protoplasm of only the first chambers is stained after storage of ten days. After fourteen days, nearly all specimens are completely stained, which is therefore considered as the minimum impregnation time. The staining and preservation with rose Bengal ethanol solution became widely accepted not earlier than in the late 1990s.

The main caveats raised against rose Bengal staining are: that adherent bacteria or algae are also vividly stained, which mimics the staining of the foraminiferal protoplasm; that the colour and intensity of the staining varied among species causing a degree of subjectivity in the assessment of whether or not a specimen is living; and, more importantly, that metabolically inactive or even decaying protoplasm of dead foraminifers is also stained (Walker et al., 1974; Bernhard, 2000). These points were discussed by Lutze \& Altenbach (1991), who also again explained the rose Bengal staining method in detail and gave examples of speciesspecific staining patterns and their possible reasons. None the less, other dyes have been tested, for instance Sudan Black B, which stains lipids and colours more living specimens than a reference array stained with rose Bengal according to Walton (1952) (Walker et al., 1974; Serrano et al., 2008). Alternatively, the content of nucleotide Adenosine Triphosphate (ATP), a substance which decays rapidly after the death of a living cell (DeLaca, 1986), is determined. Comparative studies have demonstrated that rose Bengal may stain more tests than predicted by ATP analyses (Bernhard, 1988), but later investigations on deep-sea foraminifera reveal that ATP concentrations may vary strongly and specimens at low food levels have very low ATP concentrations (Linke et al., 1995). These are hardly distinguishable from a cluster of bacteria (Linke, 1989). Fluorogenic probes like fluorescein diacetate or CellTracker Green CMFDA require an epifluorescence microscope or spectrofluorimetric equipment. They are non-terminal stains (i.e. they do not kill the organisms), but the analyses have to be made within hours after the sample was taken and the specimens were isolated (Bernhard et al., 1995; 2006). Fluorogenic probes or the novel application of MTT reduction (de Nooijer, 2007) are, therefore, considered to be more suitable for experimental than for field-based studies. Finally, the results obtained 


\begin{tabular}{|c|c|c|c|c|c|c|c|c|c|c|c|}
\hline Year & Volume & First author & Preservation & Stain & $\begin{array}{l}\text { Washing } \\
(\mu \mathrm{m})\end{array}$ & Picking & Fractionation & $\begin{array}{l}\text { Subfractions } \\
\qquad(\mu \mathrm{m})\end{array}$ & Split & $\begin{array}{c}\text { Fraction } \\
\text { studied }(\mu \mathrm{m})\end{array}$ & Other \\
\hline \multicolumn{12}{|c|}{ Journal of Foraminiferal Research } \\
\hline 2008 & $38(1)$ & Martin & & & 180 & dry & wet sieving & $\begin{array}{c}180,250 \\
300,500,833\end{array}$ & & $180-500$ & \\
\hline 2008 & $38(1)$ & Arujo & & & 62 & dry & & & quartered & $>62$ & \\
\hline 2008 & $38(1)$ & Fontanier & & $\begin{array}{l}\text { rose } \\
\text { Bengal }\end{array}$ & 63 & dry & wet sieving & 150 & & $>150$ & \\
\hline 2008 & $38(2)$ & Lobegeier & frozen & $\begin{array}{c}\text { rose } \\
\text { Bengal }\end{array}$ & 63 & dry & & & microsplitter & $>63$ & \\
\hline 2008 & $38(2)$ & Wilson & & & 63 & wet & wet sieving & 500 & total sample & $63-500$ & \\
\hline 2008 & $38(2)$ & Fontanier & $\begin{array}{l}\text { ethanol } \\
95 \%\end{array}$ & $\begin{array}{c}\text { rose } \\
\text { Bengal }\end{array}$ & 63 & wet & wet sieving & 150 & total sample & $\begin{array}{c}63-150 \\
>150\end{array}$ & \\
\hline 2008 & $38(3)$ & Heinz & ethanol & $\begin{array}{l}\text { rose } \\
\text { Bengal }\end{array}$ & 30 & wet & wet sieving & 63,125 & $1 / 2$ & $\begin{array}{c}63-125, \\
>125\end{array}$ & \\
\hline 2008 & $38(3)$ & Scott & & & 45 & wet & wet sieving & 63 & wet splitter & $45-63,>63$ & \\
\hline 2008 & $38(4)$ & Gibson & & & 63 & dry & wet sieving & 125 & & $63-125$ & \\
\hline 2008 & $38(4)$ & $\begin{array}{c}\text { Van } \\
\text { Hengstum }\end{array}$ & & & 45 & wet & & & wet splitter & $>45$ & \\
\hline 2008 & $38(4)$ & Polovodova & ethanol & $\begin{array}{l}\text { rose } \\
\text { Bengal }\end{array}$ & 63 & dry & wet sieving & 2000 & microsplitter & $63-2000$ & \\
\hline 2008 & $38(4)$ & Ivanova & $\begin{array}{l}\text { ethanol } \\
80 \%\end{array}$ & $\begin{array}{c}\text { rose } \\
\text { Bengal }\end{array}$ & 100 & dry & & & microsplitter & $>100$ & $\begin{array}{c}\text { distilled } \\
\text { water }\end{array}$ \\
\hline 2009 & $39(1)$ & Langer & & & & dry & & & & & \\
\hline 2009 & $39(1)$ & Sweetman & frozen & & 250 & wet & & & & $>250$ & \\
\hline 2009 & $39(2)$ & Altin & & & 63 & wet & & & & $>63$ & \\
\hline 2009 & $39(2)$ & Takata & $\begin{array}{c}\text { ethanol } \\
70 \%\end{array}$ & $\begin{array}{c}\text { rose } \\
\text { Bengal }\end{array}$ & 63 & dry & & & & $>63$ & \\
\hline 2009 & $39(3)$ & Diz & methanol & $\begin{array}{c}\text { rose } \\
\text { Bengal }\end{array}$ & 63 & dry & wet sieving & 125,250 & microsplitter & $>63$ & \\
\hline 2009 & $39(4)$ & Debenay & frozen & $\begin{array}{l}\text { rose } \\
\text { Bengal }\end{array}$ & 63 & wet & wet sieving & 500 & & $>63$ & flotation \\
\hline 2010 & $40(1)$ & Goldstein & & & 63 & wet & & & & $>63$ & \\
\hline 2010 & $40(1)$ & Eichler & $\begin{array}{c}\text { ethanol } \\
30 \%\end{array}$ & $\begin{array}{l}\text { rose } \\
\text { Bengal }\end{array}$ & 62 & dry & & & microsplitter & $>62$ & \\
\hline 2010 & $40(1)$ & Debenay & & & 63 & $\begin{array}{c}\text { wet and } \\
\text { dry }\end{array}$ & & & & $>63$ & \\
\hline 2010 & $40(2)$ & Mateau & & $\begin{array}{c}\text { rose } \\
\text { Bengal }\end{array}$ & 63 & dry & dry sieving & $\begin{array}{c}125,250,500 \\
1000,2000\end{array}$ & & $125-500$ & \\
\hline 2010 & $40(3)$ & Williams & & & 63 & dry & & & & $>63$ & \\
\hline 2010 & $40(3)$ & Mojtahid & $\begin{array}{l}\text { ethanol } \\
95 \%\end{array}$ & $\begin{array}{c}\text { rose } \\
\text { Bengal }\end{array}$ & 63 & wet & wet sieving & 150 & & $>150$ & \\
\hline 2010 & $40(4)$ & Dupuy & & & 50 & wet & & & & $>50$ & \\
\hline 2010 & $40(4)$ & Frezza & ethanol & $\begin{array}{l}\text { rose } \\
\text { Bengal }\end{array}$ & 63 & dry & wet sieving & 125 & microsplitter & $>125$ & \\
\hline 2010 & $40(4)$ & Wilson & $\begin{array}{c}\text { isopropyl } \\
70 \%\end{array}$ & $\begin{array}{l}\text { rose } \\
\text { Bengal }\end{array}$ & 63 & dry & dry sieving & 125 & total sample & $>125$ & \\
\hline 2010 & $40(4)$ & Pruitt & ethanol & $\begin{array}{l}\text { rose } \\
\text { Bengal }\end{array}$ & 63 & dry & wet sieving & 710 & & $63-710$ & flotation \\
\hline \multicolumn{12}{|c|}{ Journal of Micropalaeontology } \\
\hline 2008 & $27(1)$ & Wilson & $\begin{array}{c}\text { isopropyl } \\
70 \%\end{array}$ & $\begin{array}{c}\text { rose } \\
\text { Bengal }\end{array}$ & 63 & dry & dry sieving & 125 & total sample & $>125$ & \\
\hline 2009 & $28(2)$ & Polovodova & ethanol & $\begin{array}{l}\text { rose } \\
\text { Bengal }\end{array}$ & 63 & dry & wet sieving & 2000 & microsplitter & $63-2000$ & \\
\hline 2009 & $28(2)$ & Ohkawara & $\begin{array}{c}\text { formalin } \\
4 \%\end{array}$ & $\begin{array}{l}\text { rose } \\
\text { Bengal }\end{array}$ & 32 & wet & & & total sample & $>32$ & \\
\hline 2009 & $28(2)$ & Murray & & & 63 & dry & & & & $>63$ & \\
\hline
\end{tabular}

Table 1. Methods applied in Recent benthic foraminiferal studies published from 2008 to 2010. 


\begin{tabular}{|c|c|c|c|c|c|c|c|c|c|c|c|}
\hline Year & Volume & First author & Preservation & Stain & $\begin{array}{l}\text { Washing } \\
(\mu \mathrm{m})\end{array}$ & Picking & Fractionation & $\begin{array}{l}\text { Subfractions } \\
(\mu \mathrm{m})\end{array}$ & Split & $\begin{array}{c}\text { Fraction } \\
\text { studied }(\mu \mathrm{m})\end{array}$ & Other \\
\hline \multicolumn{12}{|c|}{ Marine Micropaleontology } \\
\hline 2008 & $66(2)$ & Panieri & frozen & $\begin{array}{c}\text { rose } \\
\text { Bengal }\end{array}$ & 63 & dry & & & microsplitter & $>63$ & \\
\hline 2008 & $66(3)$ & Diz & methanol & $\begin{array}{c}\text { rose } \\
\text { Bengal }\end{array}$ & 63 & dry & wet sieving & 125,250 & microsplitter & $>63,>125$ & \\
\hline 2008 & $68(3)$ & Renema & & & & & dry sieving & 125,500 & & $>500$ & \\
\hline 2008 & $69(2)$ & Berkeley & $\begin{array}{c}\text { ethanol } \\
30 \%\end{array}$ & $\begin{array}{c}\text { rose } \\
\text { Bengal }\end{array}$ & 63 & wet & & 500 & wet splitter & $63-500$ & $\begin{array}{c}\mathrm{Na}_{2} \mathrm{CO}_{3} \\
\text { buffer }\end{array}$ \\
\hline 2008 & $69(4)$ & Bubenshikova & $\begin{array}{c}\text { ethanol } \\
70 \%\end{array}$ & $\begin{array}{l}\text { rose } \\
\text { Bengal }\end{array}$ & 63 & dry & dry sieving & 125 & & $>125$ & \\
\hline 2009 & $70(1)$ & Fatela & ethanol & $\begin{array}{l}\text { rose } \\
\text { Bengal }\end{array}$ & 63 & wet & & & & $>63$ & \\
\hline 2009 & $70(3)$ & Mojtahid & $\begin{array}{l}\text { ethanol } \\
95 \%\end{array}$ & $\begin{array}{c}\text { rose } \\
\text { Bengal }\end{array}$ & 63 & wet & wet sieving & 150 & & $>63,>150$ & \\
\hline 2009 & $71(1)$ & Szarek & methanol & $\begin{array}{c}\text { rose } \\
\text { Bengal }\end{array}$ & 63 & dry & dry sieving & $150,250,1000$ & microsplitter & $>150$ & \\
\hline 2009 & $71(1)$ & Stanies-Uras & ethanol & $\begin{array}{l}\text { rose } \\
\text { Bengal }\end{array}$ & 63 & wet & & & & $>63$ & \\
\hline 2009 & $72(3)$ & Ricketts & & $\begin{array}{c}\text { rose } \\
\text { Bengal }\end{array}$ & 63 & & wet sieving & 150 & & $>150$ & \\
\hline 2009 & $73(3)$ & Berkeley & $\begin{array}{c}\text { ethanol } \\
30 \%\end{array}$ & $\begin{array}{l}\text { rose } \\
\text { Bengal }\end{array}$ & & & & & & & $\begin{array}{c}\mathrm{Na}_{2} \mathrm{CO}_{3} \\
\text { buffer }\end{array}$ \\
\hline 2009 & $73(3)$ & Milker & $\begin{array}{c}\text { ethanol } \\
96 \%\end{array}$ & $\begin{array}{c}\text { rose } \\
\text { Bengal }\end{array}$ & 63 & dry & dry sieving & 125 & microsplitter & $>125$ & \\
\hline 2010 & $76(3)$ & Schumacher & $\begin{array}{c}\text { formalin } \\
10 \%\end{array}$ & $\begin{array}{l}\text { rose } \\
\text { Bengal }\end{array}$ & 63 & & wet sieving & 150,300 & & $63-150,>150$ & \\
\hline
\end{tabular}

Table 1. (Continued)

by the rose Bengal method were considered to be as reliable as those by other methods, provided rose Bengal is used in a cautious way and critical manner (Murray \& Bowser, 2000).

\section{SAMPLE PROCESSING}

The earliest foraminiferal studies applied a very different sample processing technique than we are using today. For instance, Egger (1899) explained that samples should be taken in the outcrop from the physically weathered C-level of the topsoil, at best from beneath tree roots. In a subsequent paper, he explained that deepsea samples have to be dried before processing (Egger, 1902). The samples were crumbled by hand, put into bottles and water added. The bottles were corked and heavily shaken. Then the suspension was carefully poured out, replaced by fresh water and the procedure was repeated until the supernatant water was almost clear and a sand of fossils became visible on the bottom of the flask. The German term 'Schlämmen' (mudification) for washing a sample is probably derived from this procedure. The residue was transferred from the bottle to a porcelain dish, dried and the sample kept in corked glass vials, tin cans, cardboard boxes or paper envelopes.

Washing of foraminiferal samples through sieves became a common habit in the early part of the twentieth century. HeronAllen \& Earland (1916) used a silk screen of 250 mesh, which is $63 \mu \mathrm{m}$. Cushman (1922) washed the mud-rich samples from Dry Tortugas (Florida Keys) through an 80-mesh screen, which is 180 $\mu \mathrm{m}$. In his handbook on foraminifera, Cushman (1928) recommended that samples should be washed through nested brass sieves with meshes of 40, 80 and 200 per inch, which corresponds to 425 $\mu \mathrm{m}, 180 \mu \mathrm{m}$ and $75 \mu \mathrm{m}$. However, in his study from 1941 on Caribbean deep sea cores, he preferred to wash the samples through a series of sieves made of bolting silk cloth, probably to avoid damaging delicate specimens. Indeed, bolting silk sieves are still in use today for the collection of specific planktonic organisms from water samples because they are gentler on the organisms than metal sieves (V. Bertics, Kiel, pers. comm. 2011). Myers (1942a) washed samples from Plymouth Sound through a plankton net of bolting silk with a mesh of 125 openings per inch, which is roughly $120 \mu \mathrm{m}$. Test sieves made of brass or stainless steel cloth with standard mesh sizes were invented in the 1920s, when the scales of size limits of clastic grains were defined according to their prevailing aqueous transport mode and mineralogy (Udden, 1914; Wentworth, 1922; 1933). This was mainly an academic or sedimentological approach. The current 'Wentwort-Lane scale', with $1 \mathrm{~mm}$ as starting point and the ratio of $1 / 2$ or 2 as diameter limits of size classes, was introduced with the 'Report of the Lane Committee of the United States National Research Council' in 1947, and later adopted by DIN 4022, ISO 14688 and ASTM E11 standards. Sand is thereby defined as the grain-size range from $1 / 16$ to $2 \mathrm{~mm}(63-2000 \mu \mathrm{m})$, even though the US Department of Agriculture still recommends separating 'very fine sand', ranging from $50-100 \mu \mathrm{m}$, probably with reference to loess deposits.

Micropalaeontologists regard their results in the context of the fossil record where an empty foraminiferal test is transported and deposited as a sand grain. Therefore, it is conceivable that the mesh size for washing a sample has been chosen according to the lower limit of the sand size range. Such sieves were readily available for 


\begin{tabular}{|c|c|c|c|c|c|c|c|c|c|c|c|}
\hline Year & Volume & $\begin{array}{c}\text { First } \\
\text { author }\end{array}$ & Preservation & Stain & $\begin{array}{l}\text { Washing } \\
(\mu \mathrm{m})\end{array}$ & Picking & Fractionation & $\begin{array}{l}\text { Subfractions } \\
\qquad(\mu \mathrm{m})\end{array}$ & Split & $\begin{array}{c}\text { Fraction } \\
\text { studied }(\mu \mathrm{m})\end{array}$ & Other \\
\hline \multicolumn{12}{|c|}{ Journal of Foraminiferal Research } \\
\hline 1978 & $8(2)$ & Phleger & $\begin{array}{c}\text { weak } \\
\text { formalin }\end{array}$ & $\begin{array}{c}\text { rose } \\
\text { Bengal }\end{array}$ & & & & & & & \\
\hline 1978 & $8(3)$ & Otvos & & & 71 & dry & & & & $>71$ & flotation \\
\hline 1979 & $9(2)$ & Bates & formalin $5 \%$ & & & & & & & & ATP \\
\hline 1979 & $9(2)$ & Steineck & formalin & $\begin{array}{c}\text { rose } \\
\text { Bengal }\end{array}$ & 63 & wet & & & & $>63$ & \\
\hline 1980 & $10(3)$ & Scott & formalin $10 \%$ & $\begin{array}{c}\text { rose } \\
\text { Bengal }\end{array}$ & 63 & wet & & 500 & microsplitter & $>63,>500$ & flotation \\
\hline \multicolumn{12}{|c|}{ Marine Micropaleontology } \\
\hline 1980 & 5 & Belanger & & & 63 & dry & dry & 150 & microsplitter & $>150$ & dried before \\
\hline
\end{tabular}

Table 2. Methods applied in Recent benthic foraminiferal studies published from 1978 to 1980.

purchase from the laboratory supplier and they were also used by the sedimentologists or engineering geologists in the department. From the 1940 s to 1970 s, however, many micropalaeontologists washed their samples through sieves with $100 \mu \mathrm{m}$ mesh size. There is one note in the literature that a $63 \mu \mathrm{m}$ mesh was tried as well, but the results were the same and no real advantage is recognized (Lutze, 1960, p. 413). None the less, the $63 \mu \mathrm{m}$ size has been established during subsequent years as the appropriate mesh to wash a foraminiferal sample. For instance, 33 of 45 (73\%) studies of Recent benthic foraminifera that were published in 2008 to 2010 in the Journal of Micropalaeontology, Journal of Foraminiferal Research and Marine Micropaleontology used sieves with a 63 or $62 \mu \mathrm{m}$ mesh to wash the samples (Table 1). It has to be noted, however, that the smallest juvenile foraminifera have a size of about $20 \mu \mathrm{m}$ in diameter (Hallock, 1985; Alve \& Goldstein, 2003). On a $63 \mu \mathrm{m}$ mesh, only discoidal tests of more than $80 \mu \mathrm{m}$ in diameter will remain; smaller individuals will be washed through. This may lead to a substantial loss of the foraminiferal inventory during sample processing, in particular when reproduction events are to be constrained (Schönfeld \& Numberger, 2007).

\section{SAMPLE PREPARATION AND ANALYSIS}

\section{Size fractions}

Foraminiferal faunas are often analysed from a size fraction larger than $63 \mu \mathrm{m}$. This size fraction is separated from the sample residue after washing and drying with a test sieve of the required mesh size, for instance $125 \mu \mathrm{m}$. However, many publications report that these larger size fractions were obtained during sample processing in that the sample is washed through a series of nested sieves with a $63 \mu \mathrm{m}$ mesh at the bottom. In particular, 18 of $26(69 \%)$ studies of Recent benthic foraminifera published in 2008 to 2010 in Journal of Micropalaeontology, Journal of Foraminiferal Research and Marine Micropaleontology applied wet sieving to fractionate the sample residues (Table 1). It has to be noted, that 6 of these 26 studies used wet sieving to remove only large particles like pebbles, shells or organic detritus from the samples, which otherwise could damage fragile foraminiferal tests during subsequent sample processing. This procedure was not intended as fractionation for faunal analyses. In any case, wet sieving may invariably retain grains from smaller size fractions, for instance coarse silt (e.g. De Santis \& Barrett, 1998). The shape of the grains also induces a certain bias, as they may behave differently in water. Faunal data from samples that were fractionated by wet sieving are, therefore, comparable only with limitations to the results from dry sieved samples. This may also affect the faunal inventory.

A long-lasting debate is still ongoing about which grain size is appropriate for Recent foraminiferal studies. From a practical point of view the sieve should separate unwanted mineral grains or bioclasts from the foraminiferal tests as far as possible (Schröder et al., 1987). Slightly less than half of the recent investigations focused on the $>100 \mu \mathrm{m},>125 \mu \mathrm{m},>150 \mu \mathrm{m},>180 \mu \mathrm{m},>250 \mu \mathrm{m}$ or $>500 \mu \mathrm{m}$ fractions. The most frequently used size fractions were $>125 \mu \mathrm{m}$, which was examined in 9 of the above-mentioned 20 studies from 2008 to 2010 , and $>150 \mu \mathrm{m}$ in 7 of 20 studies (Table 1). Larger size fractions were considered in only two studies. None the less, eight studies considered a smaller subfraction also, for instance $>150 \mu \mathrm{m}$ and $63-150 \mu \mathrm{m}$, in order to make the results comparable to previous studies. The smaller subfraction was often considered in a limited number of samples only (Fontanier et al., 2006). The reasons for the choice of larger size fractions were either to facilitate microscopic work (e.g. Diz \& Francés, 2008), to concentrate the particular species or groups of interest (e.g. Van Hengstum et al., 2008), to reduce the time and effort of picking (e.g. Fontanier et al., 2008) or to keep the data 
comparable with previous studies (e.g. Schönfeld, 2001). The latter reason includes earlier studies by the author, his working group or school, or a study from other authors and areas which followed the same scientific objectives.

Scientific reasons to use a certain size fraction are rarely explained in the literature. For instance Lohmann (1978) stated as the reason for his choice of the size fraction $>250 \mu \mathrm{m}$ as not to comprehensively document the benthic foraminiferal distribution but rather to identify indicator species for environmental parameters, i.e. water mass distributions. This could be achieved readily with the larger size fraction, which also offers the advantages that the species are easier to identify and that the faunal analysis takes only a fifth of the time as that for the $>150 \mu \mathrm{m}$ fraction. In studies from the Western African and Portuguese Margin, Lutze et al. (1979) and Schönfeld \& Zahn (2000) demonstrated that this fraction efficiently eliminates re-deposited tests of small shelf and upper slope species that were displaced by downslope transport and may confer a considerable bias on the dead and fossil assemblages. As studies of the living fauna were intended to develop foraminiferal proxies to be applied to sediment cores, the living fauna was analysed in the $>250 \mu \mathrm{m}$ fraction too (Lutze \& Coulbourn, 1984; Schönfeld, 1997; 2002a, b). A comparison of samples where the benthic fauna of the size fractions $>63 \mu \mathrm{m}$ and $>250 \mu \mathrm{m}$ was analysed revealed that, on average, $18 \%$ of the living specimens $>63 \mu \mathrm{m}$ were recorded in the larger size fraction (Timm, 1992; Schönfeld et al., 2011). Only 21\% of the species recorded in the $63-250 \mu \mathrm{m}$ subfraction were also found in the $>250 \mu \mathrm{m}$ fraction (Appendix A). The majority of species in this fraction are rare or comparatively large in test size. As such, the analyses focused on a very different part of the faunal assemblage, though with a similar Fisher's alpha diversity index.

The fraction $>150 \mu \mathrm{m}$ was introduced for planktonic foraminiferal studies. Bé (1959, p. 84) found it difficult to identify with certainty juvenile specimens of less than $150 \mu \mathrm{m}$ in size. Finally the CLIMAP group recommended the use of the $>149 \mu \mathrm{m}$ size fraction as a standard in palaeoceanographic studies using planktonic foraminifera (CLIMAP, 1981; 1984; Kellogg, 1984). Even though the entire inventory and faunal dynamics are not captured by this size fraction (Bauch, 1994; Kandiano \& Bauch, 2002; Smart, 2002), this standard has none the less made it possible to create global maps of Ice Age ocean surface temperatures where many different groups contributed data (GLAMAP 2000 project, Sarnthein et al., 2003). It is conceivable that benthic foraminiferal specialists applied this size fraction following colleagues working with the planktonic foraminifera because they recognized it as being very effective, a possibility that has been mentioned by Parker (1954, p. 457). Census data from samples where the size fractions $>63 \mu \mathrm{m}$ and $>150 \mu \mathrm{m}$ were analysed revealed that, on average, $27 \%$ of living specimens in the deep sea and $11 \%$ in shallow waters would be captured if only the larger size fraction was examined (Fontanier et al., 2006; 2008; Mojtahid et al., 2009) (Appendix A). Only 47\% of the deep-sea and $61 \%$ of the shallow-water species were recorded in the $>150 \mu \mathrm{m}$ fraction as compared to the $>63 \mu \mathrm{m}$ fraction. A considerable loss in diversity is also recognized as the Fisher's alpha index was lower by 5.2, on average, in the $>150 \mu \mathrm{m}$ fraction.

The use of the size fraction $>125 \mu \mathrm{m}$ was recommended by Hermelin (1986), who found it difficult to identify smaller, juvenile specimens in the $63-125 \mu \mathrm{m}$ fraction because they lack many features of adult forms. This approach was rejected by Ohkushi et al. (2000) because smaller phytodetritus feeders, which occasionally dominate the faunal assemblages, are also excluded. A detailed comparison of the $>150 \mu \mathrm{m},>125 \mu \mathrm{m}$ and $>63 \mu \mathrm{m}$ size fractions likewise showed the loss of environmentally sensitive species, for instance Eponides pusillus Parr, 1950 or Adercotryma glomeratum (Brady, 1878), when considering only the larger size fractions (Schröder et al., 1987). Separation with a $125 \mu \mathrm{m}$ sieve was recommended but preference was given to the $>63 \mu \mathrm{m}$ fraction for palaeoceanographic studies with benthic foraminifera. The same effects were recognized in a comparison of $>125 \mu \mathrm{m}$ and $>250 \mu \mathrm{m}$ size fractions (Van Marle, 1988). Many environmentally indicative taxa, for instance Bolivina and Epistominella species, were found only in the smaller size fraction and thus their information would be lost when the fraction $>250 \mu \mathrm{m}$ is analysed. However, there are more recent data available for a detailed comparison of the size fractions $>63 \mu \mathrm{m}$ and $>125 \mu \mathrm{m}$ (Kurbjeweit et al., 2000; Heinz et al., 2008; Alve, 2010) (Appendix A). In the $>125 \mu \mathrm{m}$ fraction, on average $51 \%$ of the living specimens are captured and $72 \%$ of the species inventory are recorded as compared to the $>63 \mu \mathrm{m}$ fraction. The Fisher's alpha index was lower, on average, by 2.9 in the $>125 \mu \mathrm{m}$ fraction than in the $>63 \mu \mathrm{m}$ fraction in that the diversity loss was very small.

\section{Flotation}

A technique used to concentrate foraminiferal tests from quartzrich sample residues is flotation in liquids of high density or viscosity. Oil, bromoform, carbon tetrachloride, trichlorethylene or a saturated solution of sodiummetatungstate have been used (e.g. Franke, 1930; Haake, 1962; Musterman \& Kersthold, 1996). A dry sample residue is gently tipped into the liquid, the mineral grains sink to the bottom, and the foraminiferal tests and organic particles remain floating on the surface or are kept in suspension. Parallel examinations of concentrate and residue revealed a recovery rate of $93 \%$ of all foraminiferal tests (Lutze, 1968). However, this method is not applicable for species living attached to larger particles. Heavy arenaceous tests, for instance of Reophax species, also tend to sink down. A more serious problem is the open handling of the separation liquid as most of them are harmful and toxic substances. With reference to laboratory safety and long-term health effects they should be avoided. Flotation was applied in only 2 of 45 (4\%) studies published in 2008 to 2010, while it was used in 4 of $11(36 \%)$ studies published between 1978 and 1980 .

\section{Splitting}

Before a sample is quantitatively analysed, it often has to be reduced to a practical size. This sample part should contain a sufficient number of specimens to allow an assessment of species proportions and diversity indices with the required accuracy. A total number of 200-300 specimens is deemed to meet these requirements in most studies, though a lower number might be sufficient in low-diversity assemblages (Dryden, 1931; Patterson \& Fishbein, 1989; Fatela \& Taborda, 2002). It has to be noted that splitting artificially reduces the sample size and thus the probability of encountering species with a low population density or specific microhabitat preferences (Dennison \& Hay, 1967). Dry sample residues can subdivided with a microsplitter as invented by Otto (1933) for heavy mineral samples (Fig. 1). The use of this device in benthic foraminiferal studies was first mentioned by 
Bandy (1961). The accuracy of species composition in subsamples made by an Otto splitter was documented by Guptill et al. (1976, table 1). They compared the planktonic foraminiferal assemblage composition of $1 / 8$ split with 682 specimens with the composition of the total sample with 5104 individuals which were counted before splitting. The differences in species proportions between the split and the total sample varied between $0.02 \%$ and $3.81 \%$ and were, on average, $0.64 \%$. The bias was considered to depend on shape and size differences among the individual species. However, the absolute number of 682 specimens in this $1 / 8$ split inferred that the subsample was larger by $6.9 \%$ than the expected amount that should contain 638 tests only. Others noted that the number of individuals in subsamples made by an Otto splitter may even vary by $10-20 \%$ with reference to the expected values (Scott \& Hermelin, 1993). A careful handling of the splitter can reduce the differences to between $1 \%$ and $3 \%$ (W. Kuhnt, Kiel, pers. comm. 2011). This has consequences for the calculation of abundances or population densities. It has to be emphasized that such estimates can be accurate only if the splits were weighed before foraminiferal analyses (e.g. Caruso et al., 2011).

Foraminiferal assemblages from salt marshes, estuaries or deep-sea canyons frequently contain delicate or organic-walled species. They collapse and cannot be identified with certainty once they are dried. Such samples have to be processed, prepared and analysed in a wet stage. In order to split such samples to a manageable size, an adapted plankton or wet splitter has been employed (e.g. Motoda, 1959; Scott \& Hermelin, 1993). The accuracy of such devices is in the range of 5-30\% (Van Guelpen et al., 1982; Tennant \& Baker, 1992). However, as sorting and fractionation is a common feature in suspensions of sand-sized particles, the operation of a wet splitter requires a high level of practice in order to obtain representative and accurate subsamples.

\section{Faunal analyses}

Since the pioneering work of Bandy et al. (1964a, b), most studies on Recent benthic foraminifera have followed a quantitative approach in that the species composition of the assemblages and their population densities or absolute abundances are assessed. The latter refers to the total number of individuals that were living at the time of sampling or the empty tests to a unit volume or sample weight, for instance $10 \mathrm{~cm}^{3}$ or $1 \mathrm{~g}$ of dry sediment. The unit volume was introduced by Phleger et al. (1953). Phleger stated that he had considered samples taken by such a variety of devices for his Gulf of Mexico studies that the abundances of species have to be referred to a common standard. He preferred $10 \mathrm{~cm}^{3}$, ideally the topmost $2 \mathrm{~cm}$ of his Phleger (1951) corer with a tube of $2.5 \mathrm{~cm}$ inner diameter. At present, many near-shore studies keep with Phleger's concept and refer to the population density as number of living individuals per sample volume of $10 \mathrm{~cm}^{3}$. Commonly, a tube of $3.6 \mathrm{~cm}$ inner diameter is used and the uppermost $1 \mathrm{~cm}$ is taken to facilitate a standard volume of $10 \mathrm{~cm}^{3}$ (Scott \& Medioli, 1980). Deep-sea studies often use $50 \mathrm{~cm}^{3}$ as reference. This corresponds to a $1 \mathrm{~cm}$ slice from a tube of $8 \mathrm{~cm}$ inner diameter.

Faunal analyses, in particular examination and picking, are not only pure microscopic work but also involve different techniques. In the 1960 and 1970s, it was a common habit only to count. The foraminiferal specimens in the sample residue were recognized by eye, determined from personal memory if the observer was familiar with the species present, and counted. A grid of white or brass lines on the bottom of the microscope picking tray facilitates the orientation at high magnifications and helps to ensure that a particular specimen is not counted twice. The census was recorded with a tally sheet, numerical keyboard or dictaphone. The counted split was archived in a separate glass vial, or it was poured back into the sample residue. The background idea was that the split itself was representative and repeatable. Any other observer would obtain the same data with negligible errors if the person counted the same split again. In reality, such replicate analyses were rarely carried out and, if so, they were not reported in the literature. Many micropalaeontologists regard the distribution of specimens in the sample split and also on the picking tray as even and homogeneous (e.g. Drooger \& Kaasschieter, 1958; Weiss, 2011), which, in fact, is not the case (Boltovskoy \& Wright, 1976, p. 335). Many workers have terminated the census when the required minimum number of specimens was achieved, leaving parts of the sample unregarded (e.g. Seiglie, 1966). Only publications where it is explicitly stated that the entire sample or split was analysed are considered to meet the precondition of quantitative faunal analyses.

In order to improve the reliability of pure counting, a representative or 'typical' specimen of each species was selected and mounted individually in a designated square of a Plummer cell slide (Fig. 1). This is also applied to as yet unidentified specimens, which thereafter are recorded in open nomenclature by the number of the square, where the example specimen was placed, for instance 'Reophax sp. 19'. Such reference slides were even for sale from commercial laboratory suppliers. Other micropalaeontologists count while picking and keep the whole assemblage for reference in a single cell slide. The taxonomic concept, at least of the most frequent species, is documented with additional specimens that were taken from a separate part of the sample and mounted by species in single cell slides.

The late 1980s saw a merger of the picking and counting schemes. The foraminifera were first picked quantitatively from the whole sample residue or a split. Then the whole assemblage was sorted by species in Plummer cell slides, fixed with glue and counted. This procedure is rather time consuming, but it offers the advantage that both the taxonomic concept and the census are documented. It even facilitates revision and offers the opportunity to correct misidentifications. However, it has to be emphasized that this development did not happen simultaneously world-wide, and it is not accomplished to date. Some schools still count, other groups have mounted Plummer cell slides from each sample since the early days (e.g. Cushman, 1941, p. 130). The recent literature reveals that most of these picking or counting schemes are still in practice.

\section{CONCLUDING REMARKS}

Studies of Recent benthic foraminifera are numerous and go back to the mid-eighteenth century. They provide a valuable and still growing dataset on the distribution of modern benthic foraminifera. Sampling strategies and techniques, as well as laboratory protocols and faunal analysis methods were largely different in past decades compared with those of today. Despite that, many scientists are inclined to refer to the results of early studies as reference points or benchmarks for an early industrial or pre-global warming state of the foraminiferal assemblages disregarding the low geographical, hypsographic or seasonal representativeness. They 
should be considered as supplementary information rather than as indicators of true baseline conditions. Furthermore, only data on foraminifera that were living at the time of sampling rather than empty tests should be considered for any sort of baseline study.

Multiple corer, box corer and grab samplers may take accurate surface sediment samples provided that their design minimizes the bow wave when the device touches the seabed. The majority of disturbances are created, however, when the unit is placed on deck, the tubes or boxes are dismounted, and the sample is taken. Appropriate training of the staff before the research cruise, discussions and adaptations of sampling schemes according to the findings will significantly improve the data quality and thus the success of a sampling campaign.

Ethanol for sample preservation and rose Bengal as a vital stain are now widely accepted and simple to apply in Recent foraminiferal studies. With reference to already established safety regulations, an alcohol concentration of $30 \%$ should be aimed for as the sample preservative blend, at least for the transport period. A mesh size of $63 \mu \mathrm{m}$ is now widely used for sieves to wash the samples, and it will certainly become a common standard in the near future. The restriction of the faunal analyses to a larger grain-size fraction to separate unwanted mineral grains, small planktonic foraminifera or re-deposited specimens from the foraminiferal tests of interest might be necessary under certain circumstances. The size fractions $>125 \mu \mathrm{m}$ and $>150 \mu \mathrm{m}$ are most commonly used today. However, the application of a larger size fraction induces a significant reduction in the number of living specimens and species richness. These losses in faunal inventory and diversity are lowest in the $>125 \mu \mathrm{m}$ fraction.

There is a much lower level of common practice in faunal analyses today than in field sampling or laboratory procedures. In general, a growing number of studies apply quantitative methods and acquire independently revisable census data. More taxonomic and methodological studies are necessary to further establish quantitative concepts in Recent benthic foraminiferal studies.

\section{ACKNOWLEDGEMENTS}

This paper arose from a plenary discussion on a standardization of methods for benthic foraminiferal surveys for environmental studies that took place during the FORAMS 2010 Symposium at Bonn, Germany, in September 2010. The encouragements of Frans Jorissen, Sergei Korsum and Elisabeth Alve chairing this ad hoc meeting and the contributions of more than 30 participants are gratefully acknowledged. Christophe Fontanier, Angers, and Petra Heinz, Tübingen, provided numerical census data from their 2006 and 2008 publications for size fraction comparisons. Alexander Altenbach, Munich, Wolfgang Kuhnt, Kiel, and Friedrich-Wilhelm Haake, Altenholz, as contemporary witnesses of developments during the 1960 s to 1980 s, made valuable suggestions on an earlier version of this paper. The efforts of John Murray and John Whittaker to review this paper are gratefully acknowledged. Finally, I would like to thank André Freiwald, Heidemarie Kassens, Helmut Kawohl, Sergej Neufeld ${ }^{\dagger}$, Wolfgang Queisser and all the boatswains and ratings on European research vessels who told me the secrets of successfully operating seagoing sampling devices.

\section{Manuscript received 3 May 2011 \\ Manuscript accepted 25 July 2011}

Scientific Editing by Alan Lord

\section{REFERENCES}

Alve, E. 1991. Benthic foraminifera in sediment cores reflecting heavy metal pollution in Soerfjord, Western Norway. Journal of Foraminiferal Research, 21: 1-19.

Alve, E. 2010. Benthic foraminiferal responses to absence of fresh phytodetritus: A two-year experiment. Marine Micropaleontology, 76: 67-75.

Alve, E. \& Goldstein, S.T. 2003. Propagule transport as key method of dispersal in benthic foraminifera (Protista). Limnology and Oceanography, 48: $2163-2170$.

Alve, E. \& Olsgardt, F. 1999. Benthic foraminiferal colonisation in experiments with copper-contaminated sediments. Journal of Foraminiferal Research, 29: 186-195.

Anderson, O.R., Lee, J.J. \& Faber, W.W., Jr. 1991. Collection, maintenance and culture methods for the study of living foraminifera. In Lee, J.J. \& Anderson, O.R. (Eds), Biology of Foraminifera. Academic Press, London, 335-357.

Baker, R.D., Hallock, P., Moses, E.F., Williams, D.E. \& Ramirez, A. 2009. Larger foraminifers of the Florida reef tract, USA: distribution patterns on reef-rubble habitats. Journal of Foraminiferal Research, 39: 267-277.

Bandy, O.L. 1961. Distribution of foraminifera, radiolaria, and diatoms in sediments of the Gulf of California. Micropaleontology, 7: 1-26.

Bandy, O.L., Ingle, J.C. Jr. \& Resig, J.M. 1964a. Foraminiferal trends, Laguna Beach outfall area, California. Limnology and Oceanography, 9: $112-123$.

Bandy, O.L., Ingle, J.C. Jr. \& Resig, J.M. 1964b. Foraminifera, Los Angeles County outfall area, California. Limnology and Oceanography, 9: $124-137$

Barnett, P.R.O., Watson, J. \& Connelly, D. 1984. A multiple corer for taking virtually undisturbed samples from shelf, bathyal and abyssal sediments. Oceanologica Acta, 7: 399-408.

Barras, C., Fontanier, C., Jorissen, F. \& Hohenegger, J. 2010. A comparison of spatial and temporal variability of living benthic foraminiferal faunas at $550 \mathrm{~m}$ depth in the Bay of Biscay. Micropaleontology, 56: 275-295.

Bauch, H.A. 1994. Significance of variability in Turborotalita quinqueloba (Natland) test size and abundance for paleoceanographic interpretations in the Norwegian-Greenland Sea. Marine Geology, 121: 129-141.

Bé, A.W.H. 1959. Ecology of Recent planktonic Foraminifera: Part 1Areal distribution in the western. North Atlantic. Micropaleontology, 5: 77-100.

Berkeley, A., Perry, C.T. \& Smithers, S.G. 2009. Taphonomic signatures and patterns of test degradation on tropical, intertidal benthic foraminifera. Marine Micropaleontology, 73: 148-163.

Bernhard, J.M. 1988. Postmortem vital staining in benthic foraminifera: Duration and importance in population and distributional studies. Journal of Foraminiferal Research, 18: 143-146.

Bernhard, J.M. 2000. Distinguishing live from dead foraminifera: methods review and proper applications. Micropaleontology, 46(suppl. 1): 38-46.

Bernhard, J.M., Newkirk, S.G. \& Bowser, S.S. 1995. Towards a non-terminal viability assay for foraminiferan protists. Journal of Eukaryotic Microbiology, 42: 357-367.

Bernhard, J.M., Ostermann, D.R., Williams, D.S. \& Blanks, J.K. 2006. Comparison of two methods to identify live benthic foraminifera: A test between Rose Bengal and CellTracker Green with implications for stable isotope paleoreconstructions. Paleoceanography, 21: PA4210, DOI: 10.1029/2006PA001290.

Bett, B.J., Vanreusel, A., Vincxs, M. et al. 1994. Sampler bias in the quantitative study of deep-sea meiobenthos. Marine Ecology Progress Series, 104: 197-203.

Blomqvist, S. 1991. Quantitative sampling of soft-bottom sediments: problems and solutions. Marine Ecology Progress Series, 72: 295-304.

Boltovskoy, E. \& Wright, R. 1976. Recent Foraminifera. W. Junk Publishers, The Hague, 515pp. 
Borja, A. \& Dauer, D.M. 2008. Assessing the environmental quality status in estuarine and coastal systems: Comparing methodologies and indices. Ecological Indicators, 8: 331-337.

Bouma, A.H. \& Marshall, N.F. 1964. A method for obtaining and analyzing undisturbed oceanic sediment samples. Marine Geology, 2: 81-99.

Brady, H.B. 1884. Report on the foraminifera dredged by H.M.S. Challenger during the years 1873-1876. Report of the scientific results of the voyage of H.M.S. Challenger, 1873-1876, Zoology, 9: 1-814.

Braun-Blanquet, J. 1964. Pflanzensoziologie. Grundzüge der Vegetationskunde. Springer Verlag, Wien, 865pp.

Bremer, M.L. \& Lohmann, G.P. 1982. Evidence for primary control of the distribution of certain Atlantic Ocean benthonic foraminifera by degree of carbonate saturation. Deep-Sea Research, 29: 987-998.

Caruso, A., Cosentino, C., Tranchina, L. \& Brai, M. 2011. Response of benthic foraminifera to heavy metal contamination in marine sediments (Sicilian coasts, Mediterranean Sea). Chemistry and Ecology, 27: 9-30.

Cigliano, M., Gambi, M.C., Rodolfo-Metalpa, R., Patti, F.P. \& HallSpencer, J.M. 2010. Effects of ocean acidification on invertebrate settlement at volcanic $\mathrm{CO}_{2}$ vents. Marine Biology, 157: 2489-2502.

CLIMAP Project Members. 1981. Seasonal reconstructions of the Earth's surface at the last glacial maximum. Geological Society of America Map and Chart Series, Technical Report MC-36: 1-18.

CLIMAP Project Members. 1984. The last Interglacial Ocean. Quaternary Research, 21: 123-224.

Culver, S.J. \& Buzas, M.A. 1980. Distribution of recent benthic foraminifera off the North American Atlantic coast. Smithsonian Contributions to the Marine Sciences, 6: 1-512.

Cushman, J.A. 1922. Shallow water foraminifera of the Dry Tortugas. Carnegie Institute of Washington, 17: 3-85.

Cushman, J.A. 1928. Foraminifera; their classification and economic use. Cushman Laboratory, Sharon, Massachusetts, 401pp.

Cushman, J.A. 1941. A study of the foraminifera contained in cores from Bartlett Deep. American Journal of Science, 239: 128-147.

Davies, J., Baxter, J., Bradley, M. et al. 2001. Marine Monitoring Handbook. Joint Nature Conservation Committee, Peterborough, 405pp.

Debenay, J.-P. \& Payri, C.E. 2010. Epiphytic foraminiferal assemblages on macroalgae in reefal environments of New Caledonia. Journal of Foraminiferal Research, 40: 36-60.

Debenay, J.-P., Tsakiridis, E., Soulard, R. \& Grossel, H. 2001. Factors determining the distribution of foraminiferal assemblages in Port Joinville Harbour (lle d'Yeu, France): the influence of pollution. Marine Micropaleontology, 43: 75-118.

DeLaca, T.E. 1986. Determination of benthic rhizopod biomass using ATP analyses. Journal of Foraminiferal Research, 16: 285-292.

Dennison, J.M. \& Hay, W. 1967. Estimating the needed sampling area for subaquatic ecologic studies. Journal of Paleontology, 41: 706-708.

DeSantis, L. \& Barrett, P.J. 1998. Grain size analysis of samples from CRP-1. Terra Antartica, 5: 375-382.

Diz, P. \& Francés, G. 2008. Distribution of live benthic foraminifera in the Ría de Vigo (NW Spain). Marine Micropaleontology, 66: 165-191.

Douglas, R.G., Wall, L. \& Cotton, M.L. 1978. The effects of sample quality in the recovery of live benthic foraminifera from the southern California borderland. Bureau of Land Management Technical Report, 20.0(2): 1-37.

Dowsett, H.J., Brunner, C.A., Verardo, S. \& Poore, R.Z. 2003. Gulf of Mexico planktic foraminifer core-top calibration data set: raw data. US Geological Survey Open-File Report, OF 03-8: 11pp, http://pubs.usgs.gov/ of/2003/of03-008/

Drooger, C.W. \& Kaasschieter, J.P.G. 1958. Foraminifera of OrinocoTrinidad-Paria Shelf. Report of the Orinoco Shelf Expedition, 4: 1-97.

Dryden, A.L. 1931. Accuracy in percentage representation of heavy mineral frequencies. Proceedings of the National Academy of Sciences, 17: 233-238.
Egger, J.G. 1893. Foraminiferen aus Meeresgrundproben, gelohtet von 1874 bis 1876 von S.M. Sch. Gazelle. Königliche Bayerische Akademie der Wissenschaften, Mathematisch-Physikalische Klasse, Abhandlungen, 18(2): 139-458.

Egger, J.G. 1899. Foraminiferen und Ostrakoden aus den Kreidemergeln der Oberbayerischen Alpen. Abhandlungen der Bayerischen Akademie der Wissenschaften, II. Klasse, I. Abteilung, 21: 1-230.

Egger, J.G. 1902. Ostrakoden aus Meeresgrundproben gelothet von 18741876 von S. M. S. Gazelle. Abhandlungen der Bayerischen Akademie der Wissenschaften, Mathematisch-Physikalische Klasse, 21: 413-477.

Ellison, R., Broome, R. \& Ogilvie, R. 1986. Foraminiferal response to trace metal contamination in the Patapsco River and Baltimore Harbour, Maryland. Marine Pollution Bulletin, 17: 419-423.

Erbacher, J. \& Nelskamp, S. 2006. Comparison of benthic foraminifera inside and outside a sulphur-oxidizing bacterial mat from the present oxygen-minimum zone off Pakistan (NE Arabian Sea). Deep-Sea Research I, 53: 751-775.

Fatela, F. \& Taborda, R. 2002. Confidence limits of species proportions in microfossil assemblages. Marine Micropaleontology, 45: 169-174.

Fontanier, C., Jorissen, F.J., Licari, L., Alexandre, A., Anschutz, P. \& Carbonel, P. 2002. Live benthic foraminiferal faunas from the Bay of Biscay: faunal density, composition, and microhabitats. Deep-Sea Research I, 49: 751-785.

Fontanier, C., Jorissen, F.J., Chaillou, G., David, C., Anschutz, P. \& Lafon, V. 2003. Seasonal and interannual variability of benthic foraminiferal faunas at $550 \mathrm{~m}$ depth in the Bay of Biscay. Deep-Sea Research I, 50: 457-494.

Fontanier, C., Jorissen, F.J., Anschutz, P. \& Chaillou, G. 2006. Seasonal variability of benthic foraminiferal faunas at $1000 \mathrm{~m}$ depth in the Bay of Biscay. Journal of Foraminiferal Research, 36: 61-76.

Fontanier, C., Jorissen, F.J., Geslin, E., Zaragosi, S., Duchemin, G., Laversin, M. \& Gaultier, M. 2008. Live and dead foraminiferal faunas from the Saint-Tropez Canyon (Bay of Fréjus): Observations based on in situ and incubated cores. Journal of Foraminiferal Research, 38: 137-156.

Franke, A. 1930. Die Trennung der Mikrofossilien aus sandigen Schlämmrückständen mit Tetrachlorkohlenstoff. Paläontologische Zeitschrift, 12: 312-314.

Fujita, K. \& Hallock, P. 1999. A comparison of phytal substrate preferences of Archaias angulatus and Sorites orbiculus in mixed macroalgalseagrass beds in Florida Bay. Journal of Foraminiferal Research, 29: $143-151$.

Gehrels, W.R. \& Newman, S.W.G. 2004. Salt-marsh foraminifera in Ho Bugt, western Denmark, and their use as sea-level indicators. Danish Journal of Geography, 104: 97-106.

Goës, A.T. 1894. A synopsis of the Arctic and Scandinavian recent marine Foraminifera hitherto discovered. Konglige Svenska VetenskapsAkademiens Handlingar, 25(9): 1-127.

Guptill, J.T., Herman, Y. \& Saunders, S.C. 1976. A new microsplitter for unconsolidated sediments. Marine Geology, 20: M15-M23.

Haake, F.-W. 1962. Untersuchungen an der Foraminiferen-Fauna im Wattgebiet zwischen Langeoog und dem Festland. Meyniana, 12: 25-64.

Hallock, P. 1985. Why are larger foraminifera large? Paleobiology, 11: 195-208.

Haynert, K., Schönfeld, J., Riebesell, U. \& Polovodova, I. 2011. Biometry and dissolution features of the benthic foraminifer Ammonia aomoriensis at high $p \mathrm{CO}_{2}$. Marine Ecology Progress Series, 432: 53-67, DOI: 10.3354/meps09138.

Hayward, B.W., Grenfell, H.R., Reid, C.M. \& Hayward, K.A. 1999. Recent New Zealand shallow-water benthic foraminifera: Taxonomy, ecologic distribution, biogeography and use in paleoenvironmental assessment. Institute of Geological and Nuclear Sciences Monograph, 21. Lower Hutt, New Zealand, 258pp. 
Hayward, B.H., Grenfell, H.R., Sabaa, A.T., Kay, J. \& Clark, K. 2011. Ecological distribution of the foraminifera in a tidal lagoon-brackish lake, New Zealand, and its Holocene origins. Journal of Foraminiferal Research, 41: 124-137.

Heinz, P., Sommer, S., Pfannkuche, O. \& Hemleben, C. 2005. Living benthic foraminifera in sediments influenced by gas hydrate at the Cascadia convergent margin, NE Pacific. Marine Ecology Progress Series, 304: $77-89$.

Heinz, P., Ruschmeier, W. \& Hemleben, C. 2008. Live benthic foraminiferal assemblages at the Pacific continental margin of Costa Rica and Nicaragua. Journal of Foraminiferal Research, 38: 215-227.

Hermelin, J.O.R. 1986. Pliocene benthic foraminifera from the Blake Plateau: faunal assemblages and paleocirculation. Marine Micropaleontology, 10: 343-370.

Heron-Allen, E. \& Earland, A. 1913. The foraminifera of the Clare Island District, County Mayo, Ireland. Proceedings of the Royal Irish Academy, 31: 1-188.

Heron-Allen, E. \& Earland, A. 1916. The foraminifera of the west coast of Scotland. Collected by Prof. W.A. Herdman, F.R.S., on the cruise of the S.Y. 'Runa', July-Sept. 1913. Being a contribution to 'Spolia Runiana'. Transactions of the Linnean Society of London, Series 2 (Zoology), 11: 197-300.

Hofker, J. 1977. The foraminifera of Dutch tidal flats and salt marshes. Netherlands Journal of Sea Research, 11: 222-296.

Hohenegger, J., Yordanova, E., Nakano, Y. \& Tatzreiter, F. 1999. Habitats of larger foraminifera on the upper reef slope of Sesoko Island, Okinawa, Japan. Marine Micropaleontology, 36: 109-168.

Honeywill, C., Paterson, D.M. \& Hagerthey, S.E. 2002. Determination of microphytobenthic biomass using pulse-amplitude modulated minimum fluorescence. European Journal of Phycology, 37: 485-492.

Horton, B.P. 1999. The distribution of contemporary of intertidal foraminifera at Cowpen marsh, Tees Estuary, UK: implications for studies of Holocene sea-level changes. Palaeogeography, Palaeoclimatology, Palaeoecology, 149: 127-149.

Hurlbert, S.H. 1984. Pseudoreplication and the design of ecological field experiments. Ecological Monographs, 54: 187-211.

Janßen, T. 2011. Meteor-Reise M83 im östlichen Nordatlantik und im Mittelmeer. Klein, aber oho - der Shipek-Greifer, http://www. senckenberg.de/root/index.php?page $\mathrm{id}=5208 \& \mathrm{id}=14$.

Jorissen, F.J. 1988. Benthic foraminifera from the Adriatic Sea; Principles of phenotypic variation. Utrecht Micropaleontology Bulletin, 37: 1-176.

Josefson, A.B., Blomqvist, M., Hansen, J.L.S., Rosenberg, R. \& Rygg, B. 2009. Assessment of marine benthic quality change in gradients of disturbance: Comparison of different Scandinavian multi-metric indices. Marine Pollution Bulletin, 58: 1263-1277.

Kandiano, E.S. \& Bauch, H.A. 2002. Implications of planktic foraminiferal size fractions for the glacial-interglacial paleoceanography of the polar North Atlantic. Journal of Foraminiferal Research, 32: 245-251.

Kellogg, T.B. 1984. Paleoclimatic significance of subpolar foraminifera in high-latitude marine sediments. Canadian Journal of Earth Sciences, 21: 189-193.

Kitazato, H., Fujikura, K., Furushima, Y., Toyofuku, T., Nomaki, H. \& Iwase, R. 2009. Long-term observation of deep-sea benthic activities in Sagami Bay, Central Japan. OceanObs'90, Additional Contributions, http://www.oceanobs09.net/proceedings/ac

Kuhn, G. \& Dunker, E. 1994. Der Minicorer, ein Gerät zur Beprobung der Sediment/Bodenwasser-Grenze. Greifswalder Geowissenschaftliche Beiträge, 2: 99-100.

Kuhnt, W., Hess, S., Holbourn, A.E., Paulsen, H. \& Salomon, B. 2005. The impact of the 1991 Mt. Pinatubo eruption on deep-sea foraminiferal communities: a model for the Cretaceous-Tertiary $(\mathrm{K} / \mathrm{T})$ boundary? Palaeogeography, Palaeoclimatology, Palaeoecology, 224: 83-107.
Kurbjeweit, F., Schmiedl, G., Schiebel, R., Hemleben, C., Pfannkuche, O., Wallmann, K. \& Schäfer, P. 2000. Distribution, biomass and diversity of benthic foraminifera in relation to sediment geochemistry in the Arabian Sea. Deep-Sea Research II, 47: 2913-2955.

Langer, M. 1993. Epiphytic foraminifera. Marine Micropaleontology, 20: 235-265.

Langezaal, A.M., Jorissen, F.J., Braun, B., Chaillou, G., Fontanier, C., Anschutz, P. \& van der Zwaan, G.J. 2006. The influence of seasonal processes on geochemical profiles and foraminiferal assemblages on the outer shelf of the Bay of Biscay. Continental Shelf Research, 26: $1730-1755$.

Linke, P. 1989. Lebendbeobachtungen und Untersuchungen des Energiestoffwechsels benthischer Foraminiferen aus dem Europäischen Nordmeer. Berichte aus dem Sonderforschungsbereich 313 'Sedimentation im Europaeischen Nordmeer', 18: 1-123.

Linke, P., Altenbach, A.V., Graf, G. \& Heeger, T. 1995. Response of deep-sea benthic foraminifera to a simulated sedimentation event. Journal of Foraminiferal Research, 25: 75-82.

Lohmann, G.P. 1978. Abyssal benthonic foraminifera as hydrographic indicators in the western South Atlantic Ocean. Journal of Foraminiferal Research, 8: 6-34.

Lutze, G.F. 1960. Zur Stratigraphie und Paläontologie des Callovien und Oxfordien in Nordwest-Deutschland. Geologisches Jahrbuch, 77: 391-532.

Lutze, G.F. 1964. Zum Färben rezenter Foraminiferen. Meyniana, 14: $43-47$.

Lutze, G.F. 1965. Zur Foraminiferen-Fauna der Ostsee. Meyniana, 15: $75-142$.

Lutze, G.F. 1968. Siedlungs-Strukturen rezenter Foraminiferen. Meyniana, 18: $31-34$.

Lutze, G.F. 1974. Foraminiferen der Kieler Bucht (Westliche Ostsee): 1. 'Hausgartengebiet' des Sonderforschungsbereiches 95 der Universität Kiel. Meyniana, 26: 9-22.

Lutze, G.F. 1980. Depth distribution of benthic foraminifera on the continental margin off NW Africa. 'Meteor' Forschungserbegnisse. Reihe C, 32: 31-80.

Lutze, G.F. \& Altenbach, A.V. 1991. Technik und Signifikanz der Lebendfärbung benthischer Foraminiferen in Bengalrot. Geologisches Jahrbuch, Reihe A, 128: 251-265.

Lutze, G.F. \& Coulbourn, W.T. 1984. Recent benthic foraminifera from the continental margin of Northwest Africa: community structure and distribution. Marine Micropaleontology, 8: 361-401.

Lutze, G.F., Sarnthein, M., Koopmann, B., Pflaumann, U., Erlenkeuser, H. \& Thiede, J. 1979. 'Meteor' Core 12309: Late Pleistocene reference section for interpretation of the Neogene of Site 397. Initial Reports Deep Sea Drilling Project, 47A: 727-739.

Lutze, G.-F., Pflaumann, U. \& Weinholz, P. 1986. Jungquartäre Fluktuationen der benthischen Foraminiferenfaunen in TiefseeSedimenten vor NW-Afrika. Eine Reaktion auf Produktivitätsänderungen im Oberflächenwasser. 'Meteor' Forschungsergebnisse, Reihe C: Geologie und Geophysik, 40: 63-180.

Lynts, G.W. 1962. Distribution of Recent foraminifera in Upper Florida bay and associated sounds. Contribution Cushman Foundation of Foraminiferal Research, 13: 127-144.

Mackensen, A., Fütterer, D.K., Grobe, H. \& Schmiedl, G. 1993. Benthic foraminiferal assemblages from the eastern South Atlantic Polar Front region between $35^{\circ}$ and $57^{\circ} \mathrm{S}$ : Distribution, ecology and fossilization potential. Marine Micropaleontology, 22: 33-69.

McIntyre, A.D. 1971. Deficiency of gravity corers for sampling meiobenthos and sediments. Nature, 231: 260.

Meischner, D. \& Rumohr, J. 1974. A light-weight, high-momentum gravity corer for subaqueous sediments. Senckenbergiana Maritima, 6: $105-117$. 
Mojtahid, M., Jorissen, F., Lansard, B., Fontanier, C., Bombled, B. \& Rabouille, C. 2009. Spatial distribution of live benthic foraminifera in the Rhône prodelta: Faunal response to a continental-marine organic matter gradient. Marine Micropaleontology, 70: 177-200.

Motoda, S. 1959. Devices of simple plankton apparatus. Memoir of the Faculty of Fisheries, Hokkaido University, 7: 73-94.

Mudroch, A. \& MacKnight, S. 1994. Handbook of techniques for aquatic sediments sampling. Lewis, Boca Raton, 210pp.

Murray, J.W. 1982. Benthic foraminifera: The validity of living, dead or total assemblages for the interpretation of palaeoecology. Journal of Micropalaeontology, 1: 137-140.

Murray, J.W. 2001. The niche of benthic foraminifera, critical thresholds and proxies. Marine Micropaleontology, 41: 1-7.

Murray, J.W. 2006. Ecology and Applications of Benthic Foraminifera. Cambridge University Press, Cambridge, 426pp.

Murray, J.W. \& Alve, E. 2000. Major aspects of foraminiferal variability (standing crop and biomass) on a monthly scale in an intertidal zone. Journal of Foraminiferal Research, 30: 177-191.

Murray, J.W. \& Bowser, S. 2000. Mortality, protoplasm decay rate, and reliability of staining techniques to recognize 'living' foraminifera: a review. Journal of Foraminiferal Research, 30: 66-70.

Murray, W.G. \& Murray, J.W. 1987. A device for obtaining representative samples from the sediment-water interface. Marine Geology, 76: 313-317.

Musterman, D. \& Kersthold, S. 1996. Sodium polytungstate, a new nontoxic alternative to bromoform in heavy liquid separation. Review of Palaeobotany and Palynology, 91: 417-422.

Myers, E. 1942a. Rate at which foraminifera are contributed to marine sediments. Journal of Sedimentary Petrology, 12: 92-95.

Myers, E. 1942b. A quantitative study of the productivity of the foraminifera in the sea. Proceedings of the American Philosophical Society, 85: $325-341$.

Nikulina, A., Polovodova, I. \& Schönfeld, J. 2008. Foraminiferal response to environmental changes in Kiel Fjord, SW Baltic Sea. eEarth, 3: 1-13.

de Nooijer, L.J. 2007. Shallow water benthic foraminifera as proxy for natural versus human-induced environmental change. Geologica Ultrajectina, 137: 1-152.

Ohkushi, K., Thomas, E. \& Kawahata, H. 2000. Abyssal benthic foraminifera from the northwestern Pacific (Shatsky Rise) during the last 298 kyr. Marine Micropaleontology, 38: 119-147.

Oleson, J.P. 2000. Ancient sounding weights: a contribution to the history of Mediterranean navigation. Journal of Roman Archaeology, 13: 294-310.

d'Orbigny, A. 1839. Foraminifères. In De La Sagra, R. (Ed.), Histoire physique, politique et naturelle de l'ile de Cuba. Arthus Bertrand, Paris, $224 \mathrm{pp}$.

Oschmann, W. 1990. Dropstones: rocky mini-islands in high latitude pelagic soft substrate environments. Senckenbergiana Maritima, 21: 55-75.

Otto, G.H. 1933. Comparative tests of several methods of sampling heavy mineral concentrates. Journal of Sedimentary Petrology, 3: 30-39.

Otvos, E.G. 1978. Calcareous benthic foraminiferal fauna in a very low salinity setting, Lake Pontchartrain, Louisiana. Journal of Foraminiferal Research, 8: 262-269.

Parker, F.L. 1954. Distribution of the foraminifera in the northeastern Gulf of Mexico. Bulletin of the Museum of Comparative Zoology at Harvard College, 111: 451-588.

Parker, F.L. 1958. Eastern Mediterranean Foraminifera. Reports of the Swedish Deep-Sea Expedition 1946-1948, 8(4): 219-283.
Patterson, R. T. \& Fishbein, E. 1989. Re-examination of the statistical methods used to determine the number of point counts needed for micropaleontological quantitative research. Journal of Paleontology, 63: $245-248$.

Petersen, C.G. 1911. Valuation of the sea. Animal life of the sea bottom, its food and quantity. Report of the Danish Biological Station, 20: $1-79$.

Phleger, F.B. 1951. Ecology of foraminifera, northwest Gulf of Mexico. Part I. Foraminifera distribution. Geological Society of America Memoir, 46: 1-88.

Phleger, F.B. 1952. Foraminifera ecology off Portsmouth, New Hampshire. Bulletin of the Museum of Comparative Zoology at Harvard College, 106: 315-390.

Phleger, F.B. \& Lankford, R.R. 1978. Foraminifera and ecological processes in the Alvarado Lagoon area, Mexico. Journal of Foraminiferal Research, 8: 127-131.

Phleger, F.B., Parker, F.L. \& Peirson, J.F. 1953. North Atlantic foraminifera. Reports of the Swedish Deep-Sea Expedition, 7: 1-122.

Rachowicz, L.J., Hubbard, A.E. \& Beissinger, S.R. 2006. Evaluating atsea sampling designs for Marbled Murrelets using a spatially explicit model. Ecological Modelling, 196: 329-344.

Regenberg, M., Steph, S., Nürnberg, D., Tiedemann, R. \& GarbeSchönberg, D. 2009. Calibrating $\mathrm{Mg} / \mathrm{Ca}$ ratios of multiple planktonic foraminiferal species with $\delta^{18} \mathrm{O}$ calcification temperatures: Paleothermometry for the upper water column. Earth Planetary Science Letters, 278: 324-336.

Reineck, H.E. 1958. Über das Härten und Schleifen von Lockersedimenten. Senckenbergiana Lethaea, 39: 49-56.

Rhumbler, L. 1935. Rhizopoden der Kieler Bucht, gesammelt durch A. Remane. I. Teil. Schriften des naturwissenschaftlichen Vereins Schleswig-Holstein, 21: 143-194.

Riddle, M.J. 1989. Bite profiles of some benthic grab samplers. Estuarine Coastal Shelf Science, 29: 285-292.

Sarnthein, M., Gersonde, R., Niebler, S. et al. 2003. Overview of Glacial Atlantic Ocean Mapping (GLAMAP 2000). Paleoceanography, 18(2): 1030, DOI: $10.1029 / 2002$ PA000769.

Schafer, C.T. 1973. Distribution of foraminifera near pollution sources in Chaleur Bay. Water Air and Soil Pollution, 2: 219-233.

Schönfeld, J. 1997. The impact of the Mediterranean Outflow Water (MOW) on Benthic foraminiferal assemblages and surface sediments at the southern Portuguese continental margin. Marine Micropaleontology, 29: 211-236.

Schönfeld, J. 2001. Benthic foraminifera and pore-water oxygen profiles. A re-assessment of species boundary conditions at the western Iberian Margin. Journal of Foraminiferal Research, 31: 86-107.

Schönfeld, J. 2002a. A new benthic foraminiferal proxy for near-bottom current velocities in the Gulf of Cadiz, northeastern Atlantic Ocean. Deep-Sea Research I, 49: 1853-1875.

Schönfeld, J. 2002b. Recent benthic foraminiferal assemblages in deep high-energy environments from the Gulf of Cadiz (Spain). Marine Micropaleontology, 44: 141-162.

Schönfeld, J. 2006. Taxonomy and distribution of the Uvigerina peregrina plexus in the tropical to northeastern Atlantic. Journal of Foraminiferal Research, 36: 355-367.

Schönfeld, J. \& Numberger, L. 2007. Seasonal dynamics and decadal changes of benthic foraminiferal assemblages in the western Baltic (NW Europe). Journal of Micropaleontology, 26: 47-60.

Schönfeld, J. \& Zahn, R. 2000. Late Glacial to Holocene history of the Mediterranean Outflow. Evidence from benthic foraminiferal 
assemblages and stable isotopes at the Portuguese Margin. Palaeogeography, Palaeoclimatology, Palaeoecology, 159: 85-111.

Schönfeld, J., Dullo, W.-Chr., Pfannkuche, O., Freiwald, A., Rüggeberg, A., Schmidt, S. \& Weston, J. 2011. Recent benthic foraminiferal assemblages from cold-water coral mounds in the Porcupine Seabight. Facies, 57: $187-213$.

Schröder, C.J., Scott, D.B. \& Medioli, F.S. 1987. Can smaller benthic foraminifera be ignored in paleoenvironmental analyses? Journal of Foraminiferal Research, 17: 101-105.

Scott, D.B. \& Hermelin, J.O.R. 1993. A device for precision splitting of micropaleontological samples in liquid suspension. Journal of Paleontology, 67: 151-154.

Scott, D.B. \& Medioli, F.S. 1980. Quantitative studies of marsh foraminiferal distributions in Nova Scotia and comparison with those in other parts of the world: implications for sea-level studies. Cushman Foundation Special Publication, 17: 1-58.

Scott, D.B., Medioli, F.S. \& Schafer, C.T. 2004. Monitoring in Coastal Environments using Foraminifera and Thecamoebian Indicators, 2nd edn. Cambridge University Press, Cambridge, 177pp.

Seiglie, G.A. 1966. Distribution of foraminifers in the sediments of Araya-Los Testigos shelf and upper slope. Caribbean Journal of Science, 6: 93-118.

Semeniuk, T.A. 2000. Spatial heterogeneity varying to homogeneity in epiphytic foraminifera from micro- to regional scale. Journal of Foraminiferal Research, 30: 99-109.

Sen Gupta, B.K. \& Smith, L.E. 2010. Modern benthic foraminifera of the Gulf of Mexico: a census report. Journal of Foraminiferal Research, 40: $247-265$.

Serrano, O., Serrano, L. \& Mateo, M.A. 2008. Effects of sample pretreatment on the $\delta^{13} \mathrm{C}$ and $\delta^{18} \mathrm{O}$ values of living benthic foraminifera. Chemical Geology, 257: 218-220.

Sharifi, A.R., Croudace, L.W. \& Austin, R.L. 1991. Benthic foraminiferids as pollution indicators in Southampton Water, southern England, United Kingdom. Journal of Micropaleontology, 10: 109-113.

Shipek, C.J. 1965. A new deep sea oceanographic system. Ocean Science and Ocean Engineering 1965, 2: 999-1008.

Shirayama, Y. \& Fukushima, T. 1995. Comparison of deep-sea sediments and overlying water collected using multiple corer and box corer. Journal of Oceanography Japan, 51: 75-82.

Smart, C.W. 2002. A comparison between smaller $(>63 \mu \mathrm{m})$ and larger $(>150 \mu \mathrm{m})$ planktonic foraminiferal faunas from the Pleistocene of ODP Site 1073 (Leg 174A), New Jersey margin, NW Atlantic Ocean. Journal of Micropalaeontology, 21: 137-147.

Smith, K.L. \& Howard, J.D. 1972. Comparison of a grab sampler and large volume corer. Limnology and Oceanography, 17: 142-145.

Smith, N. 2010. An extended definition of wetlands and the impact of the loss of wetlands, http://www.articlemyriad.com/37.htm.

Smith, W. \& McIntyre, A.D. 1954. A spring-loaded bottom sampler. Journal of the Marine Biological Association of the United Kingdom, 33: $257-264$.

Soutar, A., Johnson, S., Fischer, K. \& Dymond, J. 1981. Sampling the sediment-water interface - evidence for an organic-rich surface layer. Transactions of the American Geophysical Union, 62: 905.

Stachowicz, J.J., Terwin, J.R., Whitlatch, R.B. \& Osman, R.W. 2002. Linking climate change and biological invasions: ocean warming facilitates nonindigenous species invasions. Proceedings of the National Academy of Sciences, 99: 15 497-15 500.

Tanner, Z.L. 1897. Deep-Sea Exploration. US Government Printing Office, Washington, DC, 340pp.
Tennant, D.A. \& Baker, E.T. 1992. A fast, high-precision splitter for particle suspensions. Marine Geology, 108: 247-252.

Thompson, S.K. \& Seber, G.A.F. 1996. Adaptive sampling. Wiley, New York, 265pp.

Thomsen, J., Gutowska, M.A., Saphörster, J. et al. 2010. Calcifying invertebrates succeed in a naturally $\mathrm{CO}_{2}$-rich coastal habitat but are threatened by high levels of future acidification. Biogeosciences, 7: 3879-3891.

Timm, S. 1992. Rezente Tiefseeforaminiferen aus Oberflächensedimenten des Golfes von Guinea (Westafrika) - Taxonomie, Verbreitung, Ökologie und Korngrößenfraktionen. Berichte - Reports - GeologischPaläontologisches Institut der Universität Kiel, 59: 1-192.

Tomas, E., Gapotchenko, T., Varekamp, E.C., Mecray, E.L. \& Buchholtz ten Brink, M.R. 2000. Maps of benthic foraminiferal dustribution and environmental changes in Long Island Sound between 1940s and 1990s. US Geological Survey Open-File Report, 00-304, http://pubs.usgs.gov/ of/2000/of00-304/htmldocs/chap09/index.htm.

Udden, J.A. 1914. Mechanical composition of clastic sediments. Geological Society of America Bulletin, 25: 655-744.

Van Guelpen, L., Markle, D.F. \& Duggan, D.J. 1982. An evaluation of accuracy, precision, and speed of several zooplankton subsampling techniques. Journal du Conseil Internationl pour l'Exploration de la Mer, 40: $226-236$.

Van Hengstum, P.J., Reinhardt, E.G., Beddows, P.A., Huang, R.J. \& Gabriel, J.J. 2008. Thecamoebians (testate amoebae) and foraminifera from three anchialine cenotes: low salinity faunal transitions (1.5-4.5 psu). Journal of Foraminiferal Research, 38: 305-317.

Van Marle, L.J. 1988. Bathymetric distribution of benthic foraminifera on the Australian-Irian Jaya continental margin, eastern Indonesia. Marine Micropaleontology, 13: 97-152.

Van Veen, J. 1936. Onderzockningen in de Hoofden. Landsdrukkerij, Den Haag, 252pp.

Walker, D.A., Linton, A.E. \& Schafer, C.T. 1974. Sudan Black B: A superior stain to Rose Bengal for distinguishing living from nonliving foraminifera. Journal of Foraminiferal Research, 4: 205-215.

Walton, W.R. 1952. Techniques for recognition of living Foraminifera. Contribution Cushman Foundation of Foraminiferal Research, 3: $56-60$.

Wang, P. 1983. Verbreitung der Benthos-Foraminiferen in Elbe-Ästuar. Meyniana, 35: 67-83.

Watkins, J.G. 1961. Foraminiferal ecology around the Orange County, California, ocean sewage outfall. Micropaleontology, 7: 199-206.

Weiss, W. 2011. Das Plankton-Benthos-Verhältnis im Schnellverfahren, http:// www.bgr.bund.de/cln_151/nn_322970/DE/Themen/GG_Palaeontol/Labore/ Schlaemm lab/foraminiferen benthos inhalt.html.

Wentworth, $\bar{C} . K .1922$. A scale of grade and class terms for clastic sediments. Journal of Geology, 30: 377-392.

Wentworth, C.K. 1933. Fundamental limits to the sizes of clastic grains. Science, 77: 633-634.

Wigley, R.L. 1967. Comparative efficiencies of van Veen and Smith-McIntyre grab samplers as revealed by motion pictures. Ecology, 48: 168-169.

Wilson, B. 1998. Epiphytal foraminifera1 assemblages on the leaves of the seagrasses Thalassia testudinum and Syringodium filiforme. Caribbean Journal of Science, 34: 131-132.

Wilson, B. 2008. Population structures about epiphytal foraminiferal communities, Nevis, West Indies. Journal of Micropalaeontology, 27: 63-73.

Yanko, V., Ahmad, M. \& Kaminski, M. 1998. Morphological deformities of benthic foraminiferal tests in response to pollution by heavy metals: implications for pollution monitoring. Journal of Foraminiferal Research, 28: 177-200. 


\section{APPENDIX A: COMPARISONS BETWEEN DIFFERENT GRAIN-SIZE FRACTIONS}

\begin{tabular}{|c|c|c|c|c|c|c|c|c|}
\hline Station no. & $\begin{array}{c}\text { Population } \\
\text { density } \\
>63 \mu \mathrm{m} \\
\left(\# / 50 \mathrm{~cm}^{3}\right)\end{array}$ & $\begin{array}{l}\text { Population } \\
\text { density } \\
>125 \mu \mathrm{m} \\
\left(\# / 50 \mathrm{~cm}^{3}\right)\end{array}$ & $\begin{array}{l}\text { Fisher's } \\
\text { alpha } \\
>63 \mu \mathrm{m}\end{array}$ & $\begin{array}{c}\text { Fisher's } \\
\text { alpha } \\
>125 \mu \mathrm{m}\end{array}$ & $\begin{array}{c}\text { Difference } \\
\text { in Fisher's } \\
\text { alpha }\end{array}$ & $\begin{array}{c}\text { Species } \\
>125 \mu \mathrm{m} \\
(\% \text { of }>63 \mu \mathrm{m})\end{array}$ & $\begin{array}{c}\text { Specimens } \\
>125 \mu \mathrm{m} \\
(\% \text { of }>63 \mu \mathrm{m})\end{array}$ & Source \\
\hline St. $9,0-5 \mathrm{~cm}$ & 290 & 143 & 16.2 & 13.3 & 2.9 & 72.5 & 49.4 & $\mathrm{a}$ \\
\hline St. $31,0-5 \mathrm{~cm}$ & 129 & 87 & 21.6 & 19.0 & 2.5 & 81.2 & 67.3 & $\mathrm{a}$ \\
\hline St. $41-2,0-5 \mathrm{~cm}$ & 120 & 69 & 21.8 & 17.5 & 4.3 & 72.1 & 57.4 & $\mathrm{a}$ \\
\hline St. $65,0-5 \mathrm{~cm}$ & 240 & 110 & 14.3 & 10.0 & 4.2 & 63.3 & 45.8 & $\mathrm{a}$ \\
\hline St. $76-2,0-5 \mathrm{~cm}$ & 227 & 125 & 25.4 & 22.4 & 3.0 & 76.9 & 54.9 & $\mathrm{a}$ \\
\hline St. $81-2,0-5 \mathrm{~cm}$ & 199 & 99 & 16.9 & 13.6 & 3.3 & 70.8 & 49.9 & $\mathrm{a}$ \\
\hline St. $87,0-5 \mathrm{~cm}$ & 253 & 127 & 17.5 & 12.5 & 5.0 & 66.3 & 50.0 & $\mathrm{a}$ \\
\hline 2002 & 134 & 59 & 11.4 & 6.5 & 4.9 & 54.2 & 43.7 & $\mathrm{~b}$ \\
\hline 2004 & 85 & 21 & 7.6 & 4.7 & 2.9 & 51.3 & 24.8 & $\mathrm{~b}$ \\
\hline $\mathrm{M} 33 / 1 \mathrm{MC}-3,0-1 \mathrm{~cm}$ & 80 & 40 & 12.8 & 9.8 & 3.1 & 65.8 & 50.0 & $\mathrm{c}$ \\
\hline $\mathrm{M} 33 / 1 \mathrm{MC}-13,0-1 \mathrm{~cm}$ & 440 & 285 & 18.2 & 16.1 & 2.1 & 82.3 & 64.8 & $\mathrm{c}$ \\
\hline $\mathrm{M} 33 / 1 \mathrm{MC}-15,0-1 \mathrm{~cm}$ & 520 & 455 & 15.7 & 14.9 & 0.8 & 93.2 & 87.5 & $\mathrm{c}$ \\
\hline $\mathrm{M} 33 / 1 \mathrm{MC}-19,0-1 \mathrm{~cm}$ & 175 & 75 & 10.7 & 8.7 & 2.0 & 70.7 & 42.9 & $\mathrm{c}$ \\
\hline $\mathrm{M} 33 / 1 \mathrm{MC}-25,0-1 \mathrm{~cm}$ & 45 & 25 & 11.0 & 8.9 & 2.2 & 71.4 & 55.6 & $\mathrm{c}$ \\
\hline $\begin{array}{l}\text { M33/1MC-30, } 0-1 \mathrm{~cm} \\
\text { Mean value }\end{array}$ & 40 & 15 & 5.8 & 5.7 & $\begin{array}{l}0.1 \\
2.9\end{array}$ & $\begin{array}{l}80.0 \\
71.5\end{array}$ & $\begin{array}{l}37.5 \\
52.1\end{array}$ & $\mathrm{c}$ \\
\hline
\end{tabular}

Source: a - calculated from unpublished background census data of Heinz et al. (2008) provided by Petra Heinz, Tübingen; b -: calculated from Alve (2010, table 1) by using a sample volume of c. $754 \mathrm{~cm}^{3}$ (p. 69); c - calculated from background data set of Kurbjeweit et al. (2000, http://doi.pangaea.de/10.1594/PANGAEA.735187?format=zip).

Table A1. Comparison of population densities, Fisher's Alpha index and faunal inventory between $>63 \mu \mathrm{m}$ and $>125 \mu \mathrm{m}$ grain-size fractions.

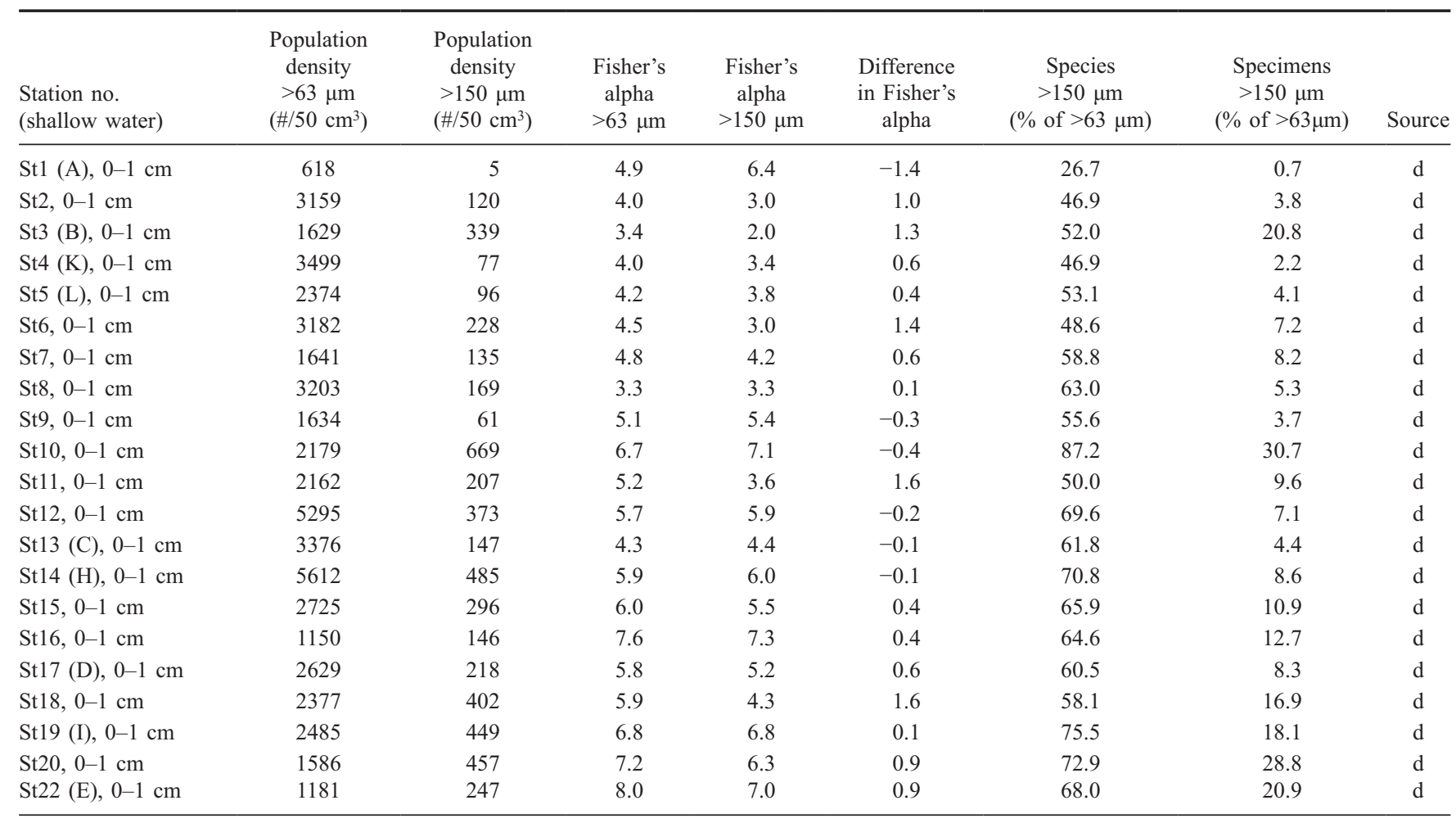

Table A2. Comparison of population densities, Fisher's Alpha index and faunal inventory between $>63 \mu \mathrm{m}$ and $>150 \mu \mathrm{m}$ grain-size fractions. 


\begin{tabular}{|c|c|c|c|c|c|c|c|c|}
\hline $\begin{array}{l}\text { Station no. } \\
\text { (shallow water) }\end{array}$ & $\begin{array}{c}\text { Population } \\
\text { density } \\
>63 \mu \mathrm{m} \\
\left(\# / 50 \mathrm{~cm}^{3}\right)\end{array}$ & $\begin{array}{l}\text { Population } \\
\text { density } \\
>150 \mu \mathrm{m} \\
\left(\# / 50 \mathrm{~cm}^{3}\right)\end{array}$ & $\begin{array}{c}\text { Fisher's } \\
\text { alpha } \\
>63 \mu \mathrm{m}\end{array}$ & $\begin{array}{c}\text { Fisher's } \\
\text { alpha } \\
>150 \mu \mathrm{m}\end{array}$ & $\begin{array}{c}\text { Difference } \\
\text { in Fisher's } \\
\text { alpha }\end{array}$ & $\begin{array}{c}\text { Species } \\
>150 \mu \mathrm{m} \\
(\% \text { of }>63 \mu \mathrm{m})\end{array}$ & $\begin{array}{c}\text { Specimens } \\
>150 \mu \mathrm{m} \\
(\% \text { of }>63 \mu \mathrm{m})\end{array}$ & Source \\
\hline St23, 0-1 cm & 2277 & 355 & 6.9 & 6.2 & 0.7 & 67.3 & 15.6 & d \\
\hline St24, 0-1 cm & 2808 & 398 & 7.2 & 7.0 & 0.2 & 71.2 & 14.2 & d \\
\hline Mean value & & & & & 0.5 & 60.6 & 11.4 & \\
\hline OB3A, $0-0.5 \mathrm{CM}$ & 1171 & 206 & 16.4 & 8.6 & 7.8 & 38.5 & 17.6 & $\mathrm{e}$ \\
\hline OB4A, $0-0.5 \mathrm{CM}$ & 800 & 129 & 11.4 & 5.6 & 5.9 & 35.6 & 16.1 & $\mathrm{e}$ \\
\hline OB5A, 0-0.5 CM & 931 & 175 & 13.2 & 7.2 & 6.0 & 40.4 & 18.8 & e \\
\hline OB6A, 0-0.5 CM & 246 & 114 & 11.4 & 6.5 & 4.9 & 53.1 & 46.3 & e \\
\hline OB7A, 0-0.5 CM & 315 & 119 & 9.7 & 5.3 & 4.5 & 48.4 & 37.9 & e \\
\hline MEAN VALUE & & & & & 5.2 & 47.0 & 26.8 & \\
\hline
\end{tabular}

Source: d - calculated from Mojtahid et al. (2009, Appendix A, supplementary data); e - calculated from unpublished background census data of Fontanier et al. (2006) provided by Christophe Fontanier, Angers;. f - calculated from Fontanier et al. (2008, Appendix II and III, http://www.cushmanfoundation.org/jfr/index.html, JFR Article Data Repository Item No. JFR DR200803).

Table A2. (Continued)

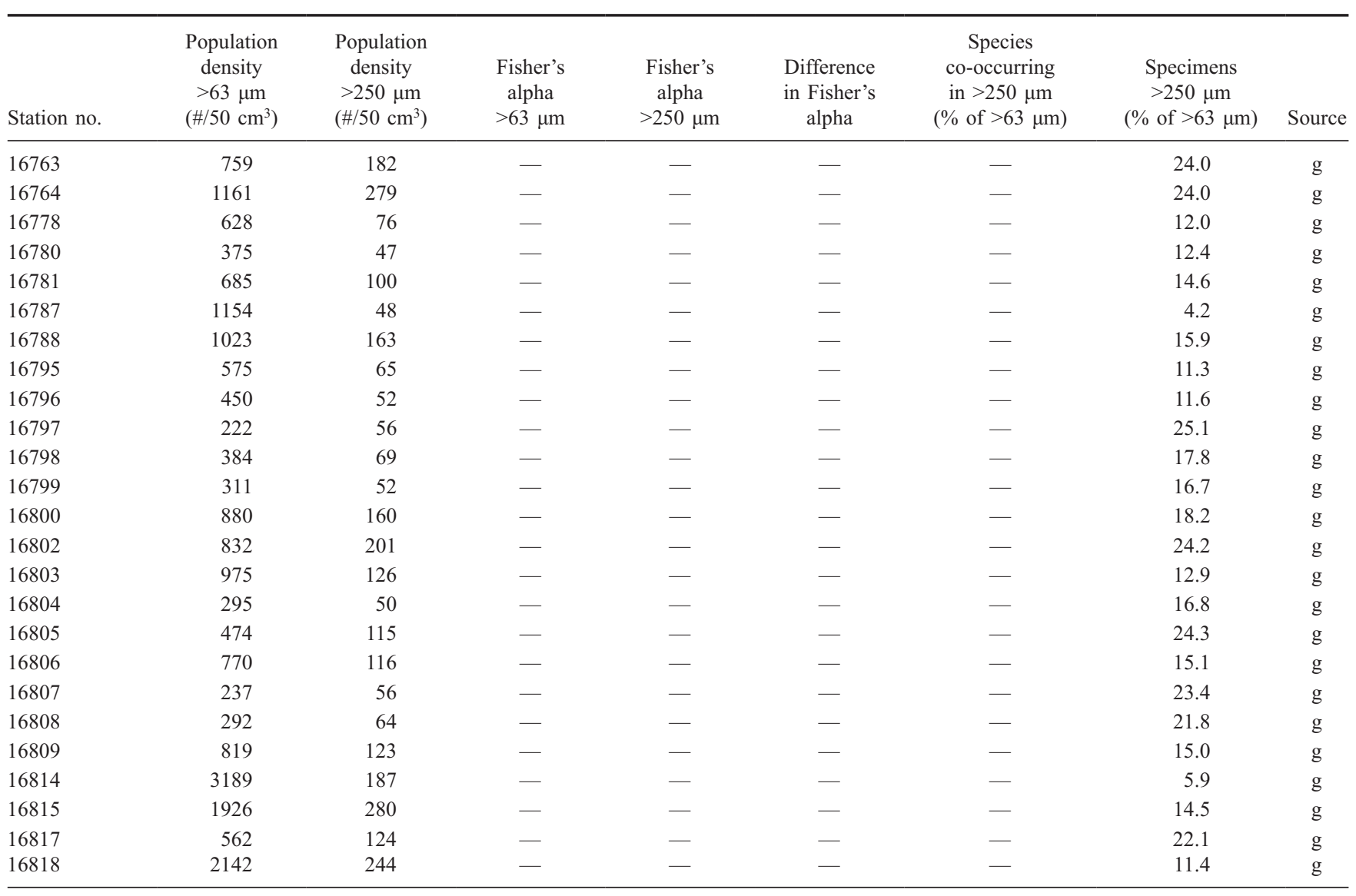

Table A3. Comparison of population densities, Fisher's Alpha index and faunal inventory between $>63 \mu \mathrm{m}$ and $>250 \mu \mathrm{m}$ grain-size fractions. 


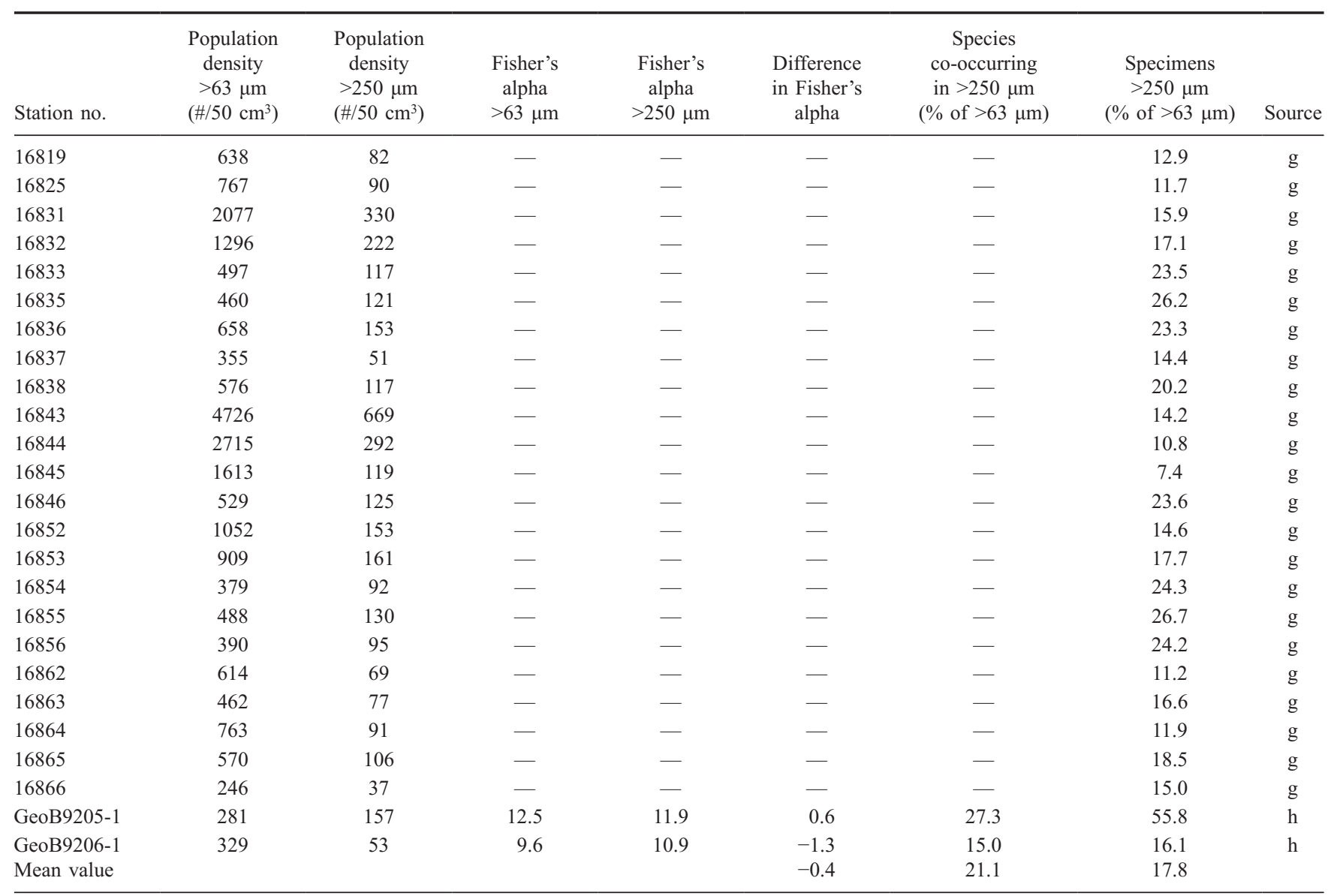

Source: g - Timm (1992, Appendix table 7); h - calculated from unpublished census data of Schönfeld et al. (2011).

Table A3. (Continued) 